\title{
Medievalista
}

Online

$31 \mid 2022$

Número 31

posibles semejanzas entre las catedrales de Tui y Braga

\section{Intercambios artísticos en una diócesis} transfronteriza

Artistic exchanges in a cross-border diocese: possible similarities between the cathedrals of Tui and Braga

\section{Marta Cendón Fernández}

\section{OpenEdition}

Journals

Edición electrónica

URL: https://journals.openedition.org/medievalista/5095

ISSN: $1646-740 \mathrm{X}$

Editor

Instituto de Estudos Medievais - FCSH-UNL

\section{Referencia electrónica}

Marta Cendón Fernández, «Intercambios artísticos en una diócesis transfronteriza», Medievalista [En línea], 31 | 2022, Publicado el 01 enero 2022, consultado el 02 febrero 2022. URL: http:// journals.openedition.org/medievalista/5095

Este documento fue generado automáticamente el 2 febrero 2022

\section{cc) (1) (9)}

Mediavalista está licenciado com uma Licença Creative Commons - Atribuição-NãoComercial 4.0 Internacional. 


\title{
Intercambios artísticos en una
} diócesis transfronteriza

\author{
Artistic exchanges in a cross-border diocese: possible similarities between the \\ cathedrals of Tui and Braga
}

Marta Cendón Fernández

\section{NOTA DEL EDITOR}

Data recepção do artigo / Received for publication: 31 de Janeiro de 2021. Data aceitação do artigo / Accepted in revised form: 12 de Novembro de 2021

\section{NOTA DEL AUTOR}

Este artículo se enmarca en el proyecto de investigación Transferencias humanas, culturales e ideológicas entre los reinos ibéricos (siglos XIII-XV), financiado por el Ministerio de Economía, Industria y Competitividad (HAR2017-89398-P) y dirigido por la Dra. Isabel Beceiro Pita (Instituto de Historia-CSIC).

\section{Una sede transfronteriza}

1 La sede tudense surge en un espacio que, con el devenir del tiempo, pertenecerá a dos países: los ríos Miño y Limia van a marcar los límites de esa parte de una diócesis, cuya capital, Tui, poseyó un papel relevante ya en época romana ${ }^{1}$. Ubicada en la vía XIX del itinerario de Antonino, que unía Braga con Astorga -con hitos relevantes en Bracara Augusta (Braga), Limia (Ponte de Lima), Tude (Tui), Turoqua (Pontevedra), Aquis Celenis (Caldas de Reyes), Iria, Lucus Augusti (Lugo) y Asturica Augusta (Astorga)- la mansio de Tui facilitará los contactos entre dichos enclaves ${ }^{2}$. 
2 Sobre ese espacio geográfico se superpone el cristianismo, cuyos orígenes son verdaderamente complejos dada la carencia de testimonios que permitan diferenciar restos romanos y los que se corresponden con la nueva religión, cuya variación se produce más en el significado que en la forma. A lo largo de la Alta Edad Media lo que conocemos mejor es aquello que se refiere a los asentamientos suevos, de los cuales cabe destacar los procedentes de las zonas urbanas del triángulo Tui-Braga-Oporto ${ }^{3}$, con la capital en $\mathrm{Braga}^{4}$. En la segunda mitad del siglo VI es cuando cristaliza la estructura diocesana. En lo que hoy es Galicia, hay que hablar de cinco sedes: Lugo, Iria, Tui, Bretoña y Ourense ${ }^{5}$ y en el actual Portugal, Braga, Dumio, Oporto, Viseu, Coimbra, Lamego e Idanha ${ }^{6}$. En el Parroquial Suevo o Divisio Theodomiri (570-580), Tui cuenta con 17 iglesias en un área relativamente pequeña, de las cuales 13 se hallarían al norte del Miño y 4 al sur.

3 Por lo que respecta a la sede tudense el primer obispo perfectamente documentado es Anila, quien regía la sede en el 572, cuando participa, con los restantes obispos del convento lucense, en el II concilio de $\mathrm{Braga}^{7}$. En realidad, la iglesia metropolitana era Braga si bien se había dividido en dos conventos o concilios (Lugo y Braga). Al primero pertenecen las sedes galaicas y Astorga, algo curioso pues Tui había estado siempre estrechamente vinculada a $\mathrm{Braga}^{8}$.

4 La integración en el Reino Visigodo, a finales del siglo VI, tampoco parece especialmente traumática y Gallaecia no sufrirá cambios político-administrativos importantes hasta mediados del $\mathrm{VII}^{9}$. Sin embargo, desde el punto de vista de la organización religiosa Braga se refuerza como metrópoli e incluso se incorporan a ella sedes que habían dependido de Mérida. Por otro lado, Leovigildo amplía las sedes arrianas. Así en las actas del III Concilio de Toledo (589), en Tui conviven un obispo arriano - Gardingo - y uno católico - Neufila -, el primero tal vez en San Bartolomé y el segundo bajo la actual catedral ${ }^{10}$.

5 Tras la llegada de los musulmanes se produce una desarticulación de la organización episcopal, de tal modo que la reorganización posterior implicará una serie de cambios ${ }^{11}$. Es cierto que en la mitad sur de Galicia la desarticulación fue más profunda; de hecho, los obispos tudenses se instalan en Iria, en las comarcas de Faro, Bergantiños, Nendos y Soneira (tabla 1) donde permanecen hasta el 914 según la mayoría de los autores ${ }^{12}$, si bien los datos son confusos.

\begin{tabular}{|l|l|l|l|l|}
\hline TUI & IRIA/SANTIAGO & BRAGA & LUGO & OURENSE \\
\hline $\begin{array}{l}\text { San Epitacio (hacia } \\
57)^{*}\end{array}$ & & $\begin{array}{l}\text { San Pedro de } \\
\text { Rates (45-60)* }\end{array}$ & San Capitón & \\
\hline & & $\begin{array}{l}\text { Paterno II } \\
(400-405)^{13},\end{array}$ & & \\
San Evasio (hacia 82) & & $\begin{array}{l}\text { Paulo (400-415?) } \\
\text { Balconio } \\
(415-447)^{14}\end{array}$ & Agrestio (desde & \\
Ceponio (440-450)* & & $\begin{array}{l}\text { Profuturo II } \\
(537-538)\end{array}$ & & \\
& & & & \\
\hline
\end{tabular}




\begin{tabular}{|c|c|c|c|c|}
\hline $\begin{array}{l}\text { Anila (mencionado } \\
\text { en 572) } \\
\text { Primero } \\
\text { documentado. }\end{array}$ & $\begin{array}{l}\text { Andrés (firma las actas } \\
\text { del I Concilio de Braga } \\
\text { en } 561 \text { y del II Concilio } \\
\text { de Braga en 572) }\end{array}$ & $\begin{array}{l}\text { Lucrecio } \\
(561-562) \\
\text { San Martín de } \\
\text { Braga (572-579) }\end{array}$ & $\begin{array}{lr}\text { Nitigio, } & \text { Nitigis, } \\
\text { Nitigisio } & 0 \\
\text { Nitigesio (ca. } 562 \\
\text { - después de 589) }\end{array}$ & $\begin{array}{l}\text { Witimiro } \\
\text { (ca. 570) }\end{array}$ \\
\hline $\begin{array}{l}\text { Neufila (mencionado } \\
\text { en 589, católico) } \\
\text { Gardingo (antes de } \\
633 \text {, arriano) }\end{array}$ & $\begin{array}{l}\text { Dominicus (firma las } \\
\text { actas del III Concilio de } \\
\text { Toledo en 589) }\end{array}$ & $\begin{array}{l}\text { Pantardo } \\
(580-589) \\
\text { Benigno } \\
(589-612)^{*}\end{array}$ & $\begin{array}{l}\text { Becila (arriano } \\
\text { entre 585-589, } \\
\text { convertido al } \\
\text { catolicismo) }\end{array}$ & $\begin{array}{l}\text { Lupato (en } \\
589)\end{array}$ \\
\hline $\begin{array}{l}\text { Anastasio } \\
\text { (mencionado entre } \\
633 \text { y 638) }\end{array}$ & $\begin{array}{l}\text { Samuel (firma las actas } \\
\text { del IV Concilio de } \\
\text { Toledo en 633) }\end{array}$ & $\begin{array}{l}\text { Tolobeu } \\
(612-633) *\end{array}$ & & $\begin{array}{l}\text { Teodoro (en } \\
610 \text { ) }\end{array}$ \\
\hline $\begin{array}{l}\text { Adimiro } \\
\text { (mencionado en } 646 \text {, } \\
\text { en el VII Concilio de } \\
\text { Toledo en 646) }\end{array}$ & $\begin{array}{l}\text { Gotomarus (firma las } \\
\text { actas del VI Concilio de } \\
\text { Toledo en 638, y las del } \\
\text { VII Concilio de Toledo } \\
\text { en 646) }\end{array}$ & $\begin{array}{l}\text { Julián } \\
(633-653)\end{array}$ & $\begin{array}{l}\text { Vasconio (desde } \\
633 \text { a 646) }\end{array}$ & $\begin{array}{l}\text { David (entre } \\
633 \text { y 638) }\end{array}$ \\
\hline $\begin{array}{l}\text { Beato (mencionado } \\
\text { en 653, en las actas } \\
\text { del VIII Concilio de } \\
\text { Toledo) }\end{array}$ & $\begin{array}{l}\text { Vincibilis (firma las } \\
\text { actas del VIII Concilio de } \\
\text { Toledo en 653) }\end{array}$ & $\begin{array}{l}\text { Potamio } \\
(653-656) \\
\text { San Fructuoso } \\
\text { de Dume y Braga } \\
(656-660) \\
\text { Manucino } \\
(660-661) *\end{array}$ & $\begin{array}{l}\text { Ermefredo } \\
\text { (desde } 653 \text { a 656) }\end{array}$ & $\begin{array}{l}\text { Gaudisteo } \\
\text { (entre } 646 \text { y } \\
650) \\
\text { Somna } \\
\text { (entre } 653 \text { y } \\
655 \text { )b } \\
\text { Alario o }\end{array}$ \\
\hline $\begin{array}{l}\text { Genitivo (firma en } \\
675 \text {, en el III Concilio } \\
\text { de Braga, detrás del } \\
\text { metropolitano de } \\
\text { Braga y llega al XII } \\
\text { Concilio de Toledo } \\
\text { de 681) } \\
\text { Oppas (mencionado } \\
\text { en 683, en el XIII } \\
\text { Concilio de Toledo) }\end{array}$ & $\begin{array}{l}\text { Ildulfus-Félix (firma las } \\
\text { actas del III Concilio de } \\
\text { Braga en 675, del XII } \\
\text { Concilio de Toledo en } \\
681 \text {, del XIII Concilio de } \\
\text { Toledo en } 683 \text { y del XV } \\
\text { Concilio de Toledo en } \\
688 \text { ) }\end{array}$ & $\begin{array}{l}\text { Pancracio } \\
(661-675) * \\
\text { Leodegisio Julián } \\
(675-678) \\
\text { Liuva }(678-681) \\
\text { Quirico } \\
(681-687)^{*}\end{array}$ & $\begin{array}{l}\text { Rectógenes } \\
\text { (desde 657) } \\
\text { Eufrasio (desde } \\
681 \text { a 688) }\end{array}$ & $\begin{array}{l}\text { Hilario } \\
\text { (entre } 675 \text { y } \\
683 \text { ) }\end{array}$ \\
\hline $\begin{array}{l}\text { San Adelfio } \\
\text { (mencionado entre } \\
688, \text { XV Concilio de } \\
\text { Toledo y 693, XVI } \\
\text { Concilio de Toledo) }\end{array}$ & $\begin{array}{l}\text { Selva (durante } \\
\text { reinado de Witiza) }\end{array}$ & $\begin{array}{l}\text { Faustino } \\
(688-693)\end{array}$ & $\begin{array}{l}\text { Potencio (desde } \\
695)\end{array}$ & $\begin{array}{l}\text { Fructuosus } \\
\text { (activo entre } \\
688 \text { y 693) }\end{array}$ \\
\hline $\begin{array}{ll}\text { REFUGIADOS } & \text { EN } \\
\text { SANTIAGO (?) } & \end{array}$ & $\begin{array}{l}\text { Teodesindo } \\
\text { (mencionado en 709) }\end{array}$ & \begin{tabular}{|lr} 
Félix & $(693-734)$, \\
último & obispo \\
residente & en \\
Braga &
\end{tabular} & & \\
\hline
\end{tabular}




\begin{tabular}{|c|c|c|c|c|}
\hline $\begin{array}{l}\text { REFUGIADOS EN } \\
\text { SANTIAGO (?) } \\
\text { En } \\
\text { Bergantiños, Nendos } \text { Faro, } \\
\text { y Soneira }{ }^{15} \\
\text { Restauración de } \text { Tui } \\
(850-866)^{16}\end{array}$ & 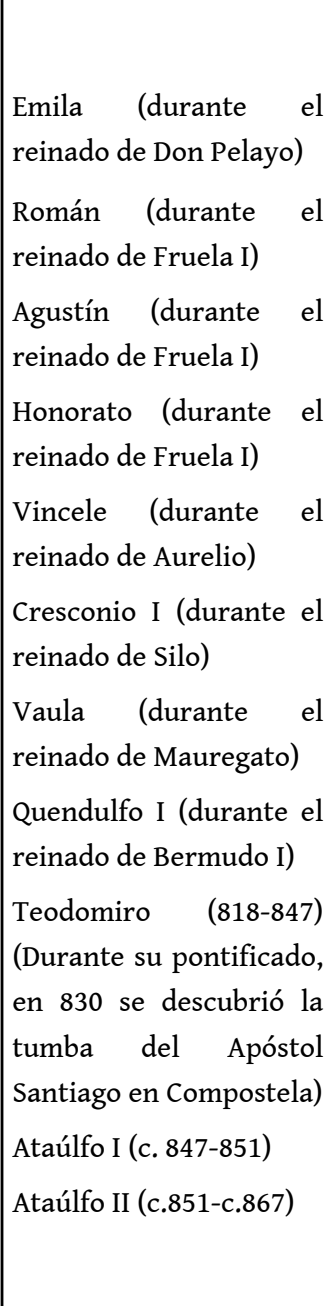 & $\begin{array}{l}\text { ESTABLECIDOS } \\
\text { EN LUGO } \\
\text { Santiago de } \\
\text { Braga (734-736) } \\
\text { Erónio (736-737) } \\
* \\
\text { Hermenegildo } \\
(737-738)^{*} \\
\text { Jacobo (738-740) } \\
* \\
\text { Odoario } \\
(740-786)^{17} \\
\text { Ascárico } \\
(780-811) * \\
\text { Argimundo } \\
(821-832) * \\
\text { Nostiano (832) }{ }^{*} \\
\text { Ataúlfo } \\
(832-840) \\
\text { Ferdizendo } \\
(840-842) * \\
\text { Dulcídio } \\
(842-850) * \\
\text { Gladila }(850-867) \\
\text { Engomado } \\
(867-875) *\end{array}$ & $\begin{array}{l}\text { Odoario (ca. 750- } \\
\text { ca. 780) } \\
\text { Adulfo (desde } \\
832) \\
\text { Gladilano } \\
(842 / 850-\text { desde } \\
861) \\
\text { Froilán (desde } \\
875-883)\end{array}$ & $\begin{array}{l}\text { Maydo } \\
(-802) \\
\text { Adulfo (en } \\
820)\end{array}$ \\
\hline $\begin{array}{l}\text { No hay nombrado } \\
\text { obispo }(881) \\
\text { Existe la sede } \\
(878-886) \\
\text { Diego }(882-900)^{18} \\
\text { Hermogio }(911 \text {-hacia } \\
920)\end{array}$ & Sisnando I (879-919). & $\begin{array}{l}\text { Flaviano } \\
(875-881) \\
\text { Flaiano } \\
(881-889) * \\
\text { Argimiro } \\
(889-910) * \\
\text { Recaredo } \\
\text { (después de 922) }\end{array}$ & $\begin{array}{l}\text { Flaviano } \\
\text { Flayano } \\
\text { desde 885) } \\
\text { Recaredo (desde } \\
885-923 / 4) .\end{array}$ & $\begin{array}{l}\text { Sebastián } \\
(877-881) \\
\text { Genserico } \\
(\text { en 884) } \\
\text { Sumna } \\
(886-890) \\
\text { Egila (en } \\
900) \\
\text { Esteban (en } \\
905)\end{array}$ \\
\hline $\begin{array}{l}\text { Branderico (antes de } \\
922-933)^{19}\end{array}$ & \begin{tabular}{|lr} 
Gundesindo & Aloitez \\
(activo en & 923 ), \\
hermano del conde & cormenegildo Aloitez
\end{tabular} & $\begin{array}{l}\text { Teodomiro } \\
(910-924) *\end{array}$ & Ero (924-941) & $\begin{array}{l}\text { Ansurio } \\
(909-922)\end{array}$ \\
\hline $\begin{array}{l}\text { Naustio (hacia 926- } \\
\text { hacia 932) }\end{array}$ & Hermenegildo (924-951) & $\begin{array}{ll}\text { Héroe/ } & \text { Hero } \\
(924-930) & \end{array}$ & & $\begin{array}{l}\text { Martín } \\
(923 / 924)\end{array}$ \\
\hline $\begin{array}{l}\text { Oveco o Eneco (hacia } \\
\text { 932-936) }\end{array}$ & & $\begin{array}{l}\text { Silvatano } \\
(930-942) *\end{array}$ & & $\begin{array}{ll}\text { Diego } & \text { I } \\
(938-954) & \end{array}$ \\
\hline
\end{tabular}




\begin{tabular}{|c|c|c|c|c|}
\hline $\begin{array}{l}\text { Vimara (936-hacia } \\
\text { 948) }\end{array}$ & & $\begin{array}{l}\text { Gonçalo/ } \\
\text { Gundisalvo } \\
(942-950)\end{array}$ & $\begin{array}{l}\text { Gonzalo/ } \\
\text { Gudesteo } \\
(942-950)\end{array}$ & \\
\hline $\begin{array}{l}\text { Baltario } \quad \text { (hacia } \\
948-951)\end{array}$ & $\begin{array}{l}\text { Sisnando Menéndez, } \\
\text { Sisnando II (951-968) }\end{array}$ & $\begin{array}{l}\text { Hermenegildo } \\
(951-985)\end{array}$ & $\begin{array}{l}\text { Hermenegildo II. } \\
\text { (951-985) }\end{array}$ & $\begin{array}{l}\text { Fredulfo } \\
(956-963)\end{array}$ \\
\hline Viliulfo (952-1003) & $\begin{array}{l}\text { San Rosendo } \\
\text { (Administrador } \\
\text { apostólico entre } \\
\text { 970-977) } \\
\text { Pelayo/Payo Rodríguez } \\
\text { (977-985), renunció }\end{array}$ & $\begin{array}{l}\text { Pelagio o Paio } \\
(986-1003)^{21}\end{array}$ & $\begin{array}{l}\text { Pelayo (985-ca. } \\
1000)\end{array}$ & $\begin{array}{l}\begin{array}{l}\text { Diego II } \\
(967-977)\end{array} \\
\text { Gonzalo } \\
(982-985) \\
\text { Vilulfo de } \\
\text { Tui } \\
(986-1003)\end{array}$ \\
\hline $\begin{array}{l}\text { Naustio? (post 1003) } \\
\text { Pelayo (inicios del } \\
\text { siglo XI) }\end{array}$ & $\begin{array}{l}\text { San Pedro de Mezonzo } \\
(985-1003)\end{array}$ & $\begin{array}{l}\text { Diego } \\
(1003-1004)\end{array}$ & $\begin{array}{ll}\text { Diego } & \text { (desde } \\
1017) & \end{array}$ & \\
\hline $\begin{array}{l}\text { Alfonso (antes de } \\
1022)^{22}\end{array}$ & $\begin{array}{l}\text { Sisnando Díaz (activo en } \\
\text { 1007) } \\
\text { Vimara Díaz (activo en } \\
1011 \text { ) }\end{array}$ & $\begin{array}{l}\text { Flaviano } \\
(1004-1017)\end{array}$ & & \\
\hline $\begin{array}{l}\text { Suario Bermúdez, de } \\
\text { Lugo (1022-1024) } \\
\text { Sede unida a Iria } \\
\text { Flavia (1024-1069) }\end{array}$ & $\begin{array}{l}\text { Vistruario (1016-1032) } \\
\text { Servando (?) } \\
\text { Cresconio II (1048-1066) } \\
\text { Gudesteo (1067-1069) }\end{array}$ & $\begin{array}{l}\text { Suario (1022) } \\
\text { Pedro } \\
(1022-1058) \\
\text { Maurelo } \\
(1058-1060) \\
\text { Sigfredo (1060) }\end{array}$ & $\begin{array}{l}\text { Suario (desde } \\
1022) \\
\text { Pedro } \\
(1022-1058) \\
\text { Maurelo } \\
(1058-1060)\end{array}$ & $\begin{array}{l}\text { Suario de } \\
\text { Lugo (1022) } \\
\text { Vimara } \\
(1042-1045)\end{array}$ \\
\hline Jorge $(1068-1072)^{23}$ & $\begin{array}{l}\text { Diego Peláez (o Diego } \\
\text { Páez) (1075-1088) }\end{array}$ & $\begin{array}{l}\text { Vistrario } \\
(1060-1070)\end{array}$ & $\begin{array}{l}\text { Vistrario } \\
(1060-1086)\end{array}$ & $\begin{array}{l}\text { Edoronio } \\
(1071-1088)\end{array}$ \\
\hline $\begin{array}{l}\text { Auderico (ca.1072- } \\
\text { hacia 1098) }\end{array}$ & $\begin{array}{l}\text { Pedro II (1088-1090) } \\
\text { Dalmacio (1094-1095) }\end{array}$ & $\begin{array}{l}\text { Pedro }(\mathrm{I}) \text { de } \\
\text { Braga }(1070 / 1- \\
1091)\end{array}$ & $\begin{array}{l}\text { Amor } \\
(1088-1096)\end{array}$ & $\begin{array}{l}\text { Pedro } \\
(1088-1096)\end{array}$ \\
\hline $\begin{array}{l}\text { Alfonso II (hacia } \\
\text { 1098-1130) }\end{array}$ & $\begin{array}{l}\text { Diego Gelmírez } \\
\text { (Administrador } \\
\text { Apostólico de 1096-1100. } \\
\text { Obispo de 1100-1120. } \\
\text { Primer arzobispo de } \\
1120-1140)\end{array}$ & $\begin{array}{l}\text { San Gerardo de } \\
\text { Moissac (1096 - } \\
1108) \\
\text { Mauricio } \\
\text { Burdino (1109 - } \\
1118) \\
\text { Paio Mendes } \\
(1118-1137)\end{array}$ & 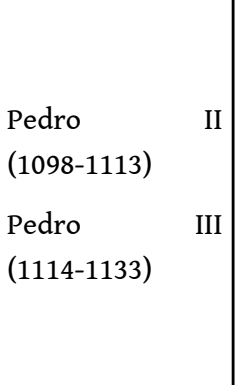 & $\begin{array}{l}\text { Diego III } \\
(1100-1132)\end{array}$ \\
\hline
\end{tabular}




\begin{tabular}{|l|l|l|l|l|}
\hline $\begin{array}{l}\text { Pelayo Meléndez } \\
(1130-1156)\end{array}$ & $\begin{array}{l}\text { Berenguel o Berengario } \\
(1140-1142)\end{array}$ & $\begin{array}{l}\text { Juan (I) Peculiar } \\
\text { Pedro Helías (1143-1149) } \\
\text { Bernardo I (1151-1152) }\end{array}$ & $\begin{array}{l}\text { Guido } \\
(1139-1175)\end{array}$ & $\begin{array}{l}\text { Martín } \\
(1134-1152)\end{array}$ \\
\hline
\end{tabular}

TABLA 1 - SEDES EPISCOPALES DE TUI, IRÍA/SANTIAgO, BRAgA, LUgO Y OURENSE HASTA MEDIADOS DEL SIgLO XII (ELABORACIÓN PROPIA).

6 Flórez considera que el obispo Nausto se retiró al monasterio de San Cristóbal de Labruja (Ponte de Lima) ${ }^{24}$, habiendo ocupado la sede tudense hacia 925, por lo que el rey Alfonso al que se refiere el documento sería Alfonso IV. Sin embargo, Carriedo concluye que ocuparía la sede después de 1003, siendo rey Alfonso V (999-1028), pues los ataques normandos serían posteriores a 968 y los musulmanes serían los de Almanzor (997) ${ }^{25}$. Por su parte López Alsina indica que es probable que se tratase del obispo de Coimbra fallecido en 912 e inhumado en el monasterio de San Andrés de Trobe ${ }^{26}$ - que hubiese administrado también el obispado tudense-, lo cual parece corroborar el hecho de que en la Crónica Albeldense entre los obispos de época de Alfonso III no se menciona a ningún obispo de Tui, así como la consagración por parte de Nausto ${ }^{27}$ de la iglesia de Santiago de Castelo de Neiva, próxima a Labruja ubicada al sur del Limia, límite de la diócesis de Tui.

7 En noviembre de 985 desaparecen los obispos de Lugo y Ourense. Esta última sede se vincula a Tui, y pasa a ser gobernada por el obispo Viliulfo que ocupaba la sede tudense desde $951^{28}$, quien sufre algunos de los ataques más crudos tanto por parte de musulmanes como normandos. Su episcopado se prolonga hasta 1003 (tabla 1). Según Mansilla se habría retirado a San Esteban de Ribas de Sil ${ }^{29}$.

8 Los ataques de los normandos -que habrían tenido lugar entre 1008 y 1016- fueron tan crudos que, a pesar del intento de reorganización llevado a cabo en 1022, Tui es anexionada a la sede de Santiago por parte de Alfonso V, el 24 de octubre de $1024^{30}$. En dicho documento de agregación se hablaba de la iglesia fundada en la ciudad de Tui bajo la advocación de san Bartolomési ${ }^{31}$ la cual, según López Alsina, no sería la catedral ubicada en Tude, que estaría destruida, sino la iglesia principal situada en Rebordáns ${ }^{32}$.

En 1068 el rey García restaura la sede de Tui en la persona del obispo don Jorge ${ }^{33}$, el cual viviría en San Bartolomés ${ }^{34}$. No se conserva el documento, pero debe de ser similar al del 1 de febrero de 1071, cuando García dona al obispo Jorge una basílica, bajo las advocaciones de Apóstol Bartolomé y la Virgen María; los mártires Sixto -obispo-, Lorenzo -arcediano- y el duque Hipólito; el mártir Jorge; el obispo y confesor Martín y san Juan Bautista ${ }^{35}$. Entre ellas se recogerían las advocaciones de las dos antiguas sedes. El documento de febrero de 1071 sería el último emanado de la cancillería de García, quien en mayo de este mismo año se vio privado de su reino, como recogió Andrade ${ }^{36}$.

10 El 13 de junio de 1071, Urraca, hermana de García y de Alfonso VI, efectúa una donación a la iglesia tudense ${ }^{37}$, que fue considerada la verdadera restauración de la sede ${ }^{38}$, en la que insiste en que, tras las diversas invasiones, se encontraba "muy pobre, y acabada". Comparando este diploma con el de 1024, López Alsina considera que existían muchas similitudes, que tal vez estarían presentes en el perdido diploma de $1068^{39}$. Como se ha indicado, la sede habría sido restaurada por García, y quizá no se podrá considerar la verdadera restauración hasta el momento en el que se reconstruya la iglesia de Santa María, es decir el traslado desde San Bartolomé. 
11 Precisamente en torno a ese año se produjo la restauración de la sede de Braga. Su fecha ha sido objeto de numerosas controversias, debido a que hay documentos interpolados donde aparece el nombre de don Pedro, que será en quien recaiga en primer lugar dicha sede tras el período de incorporación a la sede lucense (tabla 1). Lo que se puede afirmar es que se trata de uno de los firmantes de la donación de Urraca a la sede tudense, de ahí la importancia de fijar con claridad el mes en el que tal diploma fue emitido. Siguiendo el análisis documental efectuado por Avelino de Jesus da Costa, los primeros documentos de Braga en los que interviene este obispo, recogidos en el Liber Fidei ${ }^{40}$, datarían del 19 de febrero y el 27 de marzo de $1071^{41}$. Sin embargo, él mismo es consciente de que la alusión a "Petrus episcopus et canonici Bracarenses" demostraban una organización muy evolucionada de la sede, lo que hacía retrotraer su elección al año anterior (1070) y es consciente de que son documentos de data posterior a abril de $1073^{42}$. Su nombramiento en 1071 estaría confirmado por la donación a Tui en junio de 1071, pues otros documentos que él firma son las donaciones de la princesa doña Elvira a las sedes de Lugo y Ourense, que datan respectivamente del 29 y 31 de julio de $1071^{43}$.

12 Otra de las tradicionales discusiones a la hora de valorar la restauración de la sede bracarense se establece en torno a qué rey la propició, lo cual está vinculado con la fecha de su designación, pues García es depuesto por Sancho en abril, cuando lo apresa en Santarém. En febrero de 1071 se produjo la victoria de García frente a las tropas portuguesas acaudilladas por el conde Nuño Menéndez, en Pedroso, cerca de Braga ${ }^{44}$, lo que hace pensar que poseía problemas con sus súbditos del otro lado del Miño. La restauración de la metrópoli bracarense fue considerada iniciativa de García, según un documento recogido en el Liber Fidei ${ }^{45}$ conocido como Crónica de Braga, de fiabilidad problemática $^{46}$. Sin embargo lo más probable es que hubiese sido una iniciativa de Sancho II durante su breve período de control de Galicia ${ }^{47}$. En este sentido Avelino de Jesus da Costa concluye: "Como Sancho II aprisionou e destronou o irmão D. Garcia, entre o fim de Março e o 10 de Maio de 1071, a restauração da diocese e a eleição do bispo D. Pedro deviam ser em Maio deste ano, porque D. García já as tinha prometido" ${ }^{48}$. Sin embargo, como habría ocurrido en el caso tudense, en el que don García restaura la sede, sin una dote notable, que es la que se debe a la infanta Urraca, don Sancho restauraría la sede de Braga y elegiría al obispo don Pedro sin una aportación económica $^{49}$.

13 El final del episcopado de don Pedro fue brusco: su insistencia en la recuperación de la dignidad metropolitana le llevó a su destitución y reclusión en monasterio a finales de $1091^{50}$. Ciertamente Alfonso VI había nombrado a don Bernardo, abad del monasterio de Sahagún, como obispo de Toledo, siendo elevado el 15 de octubre de 1088 como primado de toda la península ${ }^{51}$. Curiosamente don Pedro no había asistido al Concilio de Husillos donde se había depuesto a Diego Peláez ${ }^{52}$, iniciador de la catedral compostelana. En marzo de 1090 se reuniría en León un concilio bajo la presidencia del legado apostólico Rainério de San Clemente. Sin embargo, sus deseos de recuperar el arzobispado para Braga se encuentran con el rechazo del legado y de Alfonso VI, considerándole continuador del rito hispano y no impulsor del romano. Por ello recurre al antipapa Clemente III, quien le habría concedido la condición de arzobispo metropolitano a inicios de $1091^{53}$. Sin embargo, de poco le sirvió ya que los restantes obispos se mantuvieron fieles a la Santa Sede, por lo que no tenía sufragáneos que le obedeciesen. Se suele considerar que el papa Urbano II habría enviado una bula para su 
deposición entre noviembre y diciembre de $1091^{54}$. La sede bracarense se encontró en un largo período de vacante hasta 1099 cuando don Bernardo, que había traído a Geraldo de Moissac, ocho años antes, lo promovería al episcopado de Braga ${ }^{55}$. En 1101 Geraldo obtendría por parte de Pascual II el palio arzobispal. Esto facilitaría la cohesión del Condado Portucalense, en manos de don Enrique, yerno de Alfonso VI, al otorgar como sufragáneas: Astorga, Lugo, Mondoñedo, Tui y Ourense en el lado español, Porto, Coimbra, Viseu y Lamego entre las portuguesas, que anteriormente se habían encontrado en la diócesis de la Lusitania ${ }^{56}$. A la muerte de Geraldo, en 1108, Mauricio Burdino fue trasladado de Coimbra a Braga ${ }^{57}$.

14 Asimismo se había intentado la restauración de otras sedes episcopales: Fernando I, tras la conquista de Coimbra en 1064, intenta restaurarla. Sin embargo, los conflictos entre sus hijos impiden que llegue el obispo Paterno hasta 1080, permaneciendo allí hasta su muerte en $1088^{58}$. Su sucesor será Cresconio, abad del monasterio de San Bartolomé de Tui ${ }^{59}$, a quien se pretendía encomendar la implantación del rito romano. Pero el gobernador de la ciudad, el mozárabe Sisnado se opone, promoviendo a Martín al episcopado -también mozárabe-, lo que retrasó la toma de posesión de Cresconio hasta el 23 de mayo 1092, prolongándose su mandato hasta 1098. En ese año es elegido el francés Mauricio Burdino ${ }^{60}$. En junio de 1071 se restaura la sede de Lamego con el nombramiento del obispo don Pedro, pero fue dependiente de Coimbra y no contó con su independencia hasta $1147^{61}$.

15 La sede de Iria, tras su traslado a Compostela, se hallaba libre de la autoridad de Braga. Desde 1100, con Diego Gelmírez como obispo, intenta reforzarse frente a Braga, en la que lleva a cabo el conocido como "Pio Latrocino", en aras de aumentar sus reliquias, con el objeto de consolidarse como el mayor centro de peregrinación de occidente ${ }^{62}$.

Por su parte, la frontera con lo que será un nuevo reino, será objeto de numerosas controversias que tienen en Tui uno de los principales centros de enfrentamientos ${ }^{63}$.

\section{La construcción de las catedrales de Braga y Tui}

17 En esta investigación se tiene en cuenta un tipo de análisis metodológico, basado en la circulación de artistas, obras y modelos como propuso Recht ${ }^{64}$, quien indicó que cabe tener en cuenta diversos aspectos: se puede producir la circulación de las obras o de los hombres, pues no solo se movían los artistas, sino también las obras y los modelos ${ }^{65}$; puede haber contactos estrechos o no con el medio local; la actividad puede extenderse dentro de un área geográfica incluso teniendo en cuenta el encargo de obras; puede existir un taller itinerante, con numerosos o pocos obreros; se debe de valorar la duración y naturaleza de la influencia ejercida entre diversos talleres ${ }^{66}$. Todo ello sin olvidar que los artistas medievales no inventan, en el sentido moderno que se da a este término, sino que se apropian de un repertorio que transforman y transmiten a su vez, lo que no les impide ser creadores ${ }^{67}$. Por su parte Guillouët profundiza en el análisis de hasta qué punto las transferencias artísticas siguen siendo una herramienta útil para la historia del arte medieval ${ }^{68}$. La identificación de los movimientos y circulación de artistas no puede obviar sus modalidades ni las condiciones de la disponibilidad de los artistas dentro de las redes de la sociedad. La permeabilidad del saber hacer y su análisis a través de la historia cultural, lleva a adoptar la noción de transferencias culturales, lo que permite cambiar los términos de la cuestión: abordarlo dentro del ámbito de los estudios históricos, puede arrojar luz sobre cuestiones como la recepción 
o difusión. Artistas, obras o modelos son los que constituyen el objeto de la investigación realizada en términos de transferencias artísticas, teniendo en cuenta el papel de estos actores y la forma en que participan en la reconfiguración de un determinado medio artístico; ello constituye un enfoque diferente, incluso en su sintaxis, una forma de ampliar la reflexión evocada por Recht. Es también una forma de sumar las aportaciones procedentes de otras disciplinas y otros horizontes historiográficos. El cambio léxico que Guillouët propone entre circulación y transferencia refleja expectativas historiográficas precisas, pues hablar de transferencias artísticas no equivale a identificar y describir la circulación de artistas, obras o modelos -aunque estas dos cuestiones, por supuesto, se superponen- si no que permite analizar la forma en la que estos movimientos de artistas, obras o modelos pueden reconfigurar los medios artísticos que les acogen o de quienes proceden ${ }^{69}$. A través de la noción de transferencias artísticas, se pasa de una problemática de recepción e influencia, al papel de los mediadores en los mecanismos de estas circulaciones y sus efectos, alcanzando más allá de las consideraciones vinculadas a la circulación y movimiento de $\operatorname{artistas}^{70}$. La historia del arte medieval revela la necesidad de estudiarla dentro de una globalidad, y, precisamente, hacerlo en términos de transferencias artísticas, circulaciones de vectores $\mathrm{y}$, sobre todo, de las reconfiguraciones a las que conducen estos movimientos, más que en términos de difusión e influencia. Por ello Guillouët concluye que el método de las transferencias culturales parece especialmente operativo para comprender las circulaciones artísticas en la Europa de la Edad Media, las modalidades según las cuales operan y, en última instancia, los significados que se les pueden atribuir ${ }^{71}$.

En nuestro caso se ha llevado a cabo un recorrido por la evolución y restauración de las sedes tudense y bracarense que tiene por objeto cotejar los paralelismos existentes entre ambas, que puedan explicar la hipótesis que en este trabajo se pretende plantear: las posibles similitudes entre el primer proyecto constructivo de la catedral de $\mathrm{Braga}^{72} \mathrm{y}$ el que consideramos que fue el de la catedral medieval de Tui ${ }^{73}$.

19 Uno de los interrogantes que se plantean tanto sobre la catedral tudense como sobre la de Braga, se refiere a la configuración primitiva de sus plantas. 

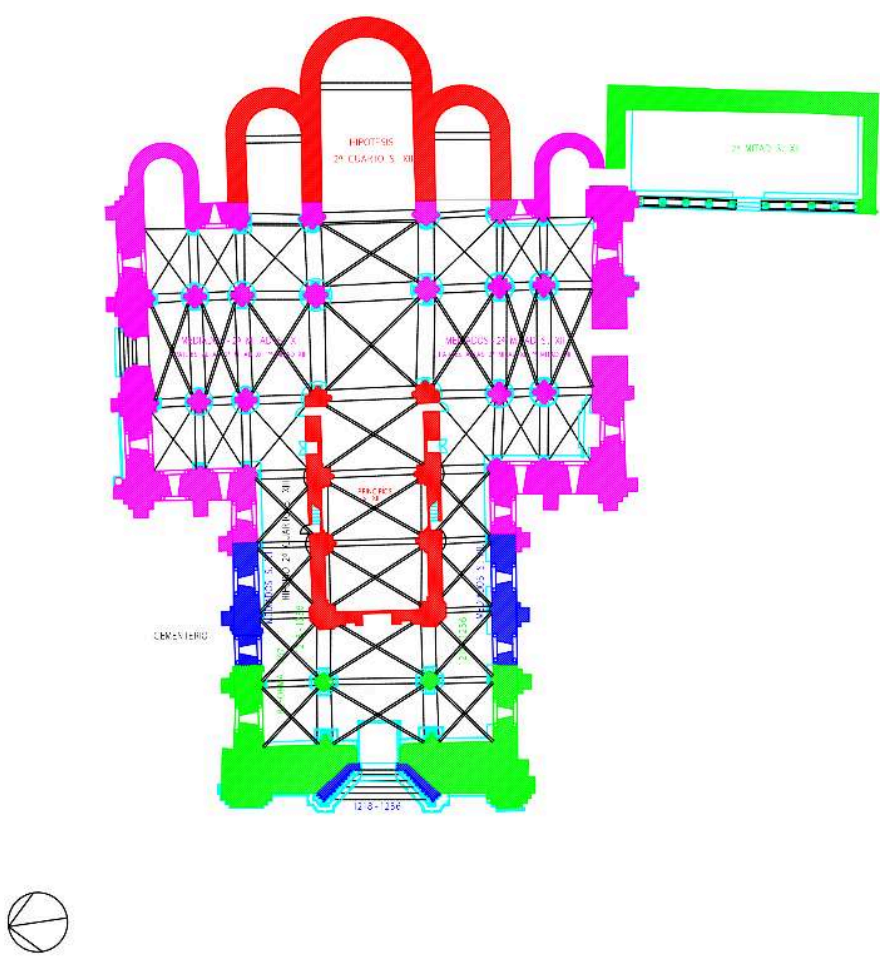

1230

Fig. 1 - Reconstrucción de la planta de LA catedral de LA Medieval de tUI, CA. 1230. PLAN DIRECTOR DE LA CATEDRAL DE TUI 2001, IAgO SEARA MORALES.

En el caso de la tudense (Fig. 1) se trata de una planta de cruz latina: el brazo mayor, muy corto, se divide en tres naves -la central más ancha-, y estas a su vez en cuatro tramos; su construcción pertenece al gótico, a un taller que Moralejo sitúa entre 1218-1236 $6^{74}$, teniendo en cuenta el inicio del episcopado de don Esteban Egea en 1218. El brazo menor está igualmente dividido en tres naves, aun cuando en este caso los tramos serán tres y más estrechos. Tradicionalmente se consideró que la catedral compostelana, por su amplio transepto, sería el modelo para Tui.

21 Sin embargo, algunos historiadores del arte que analizaron el proceso constructivo de la catedral de Braga consideraron que esta también contó con un transepto de tres naves. Es el caso de Aarão de Lacerda ${ }^{75}$, quien considera la catedral de Braga como uno de los primeros grandes edificios levantados en románico, proponiendo un trazado primitivo de enormes proporciones con cinco naves y transepto de tres naves, siguiendo el trazado conjetural de Rogério de Azevedo (Fig. 2). 


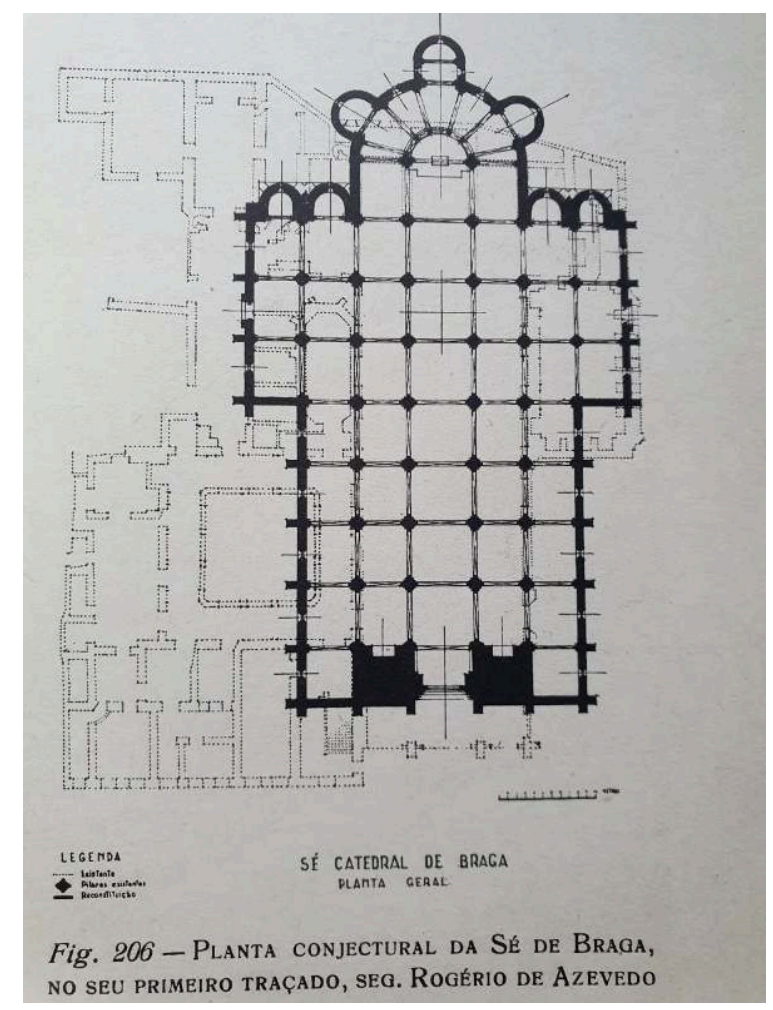

Fig. 2 - Posible planta de la primitiva catedral del Braga. Fuente: LACERDA, Aarão de - História da Arte em Portugal, vol. I, figura 206.

Por su parte Real considera que el obispo don Pedro fue el fundador de la nueva catedral y su proyecto era mucho más ambicioso que el actual, "de envergadura europeia", hasta el punto de que colocaba a Braga "numa posiçâo de relevo no proceso que condiziu à definiçâo do modelo seguido nos mais célebres santuários de peregrinaçâ" ${ }^{\prime 6}$. Sin embargo, desmiente que tal proyecto contase con un brazo mayor de cinco naves ${ }^{77}$, pero concuerda - basándose en restos rastreables en diversos pilares ${ }^{78}$ así como datos del Memorial del canónigo Tristão Luís, con respecto a las obras del episcopado de don Diogo de Sousa (1505-1532) -, con el hecho de que la basílica contaba con un transepto de tres naves ${ }^{79}$ (Fig. 3). 


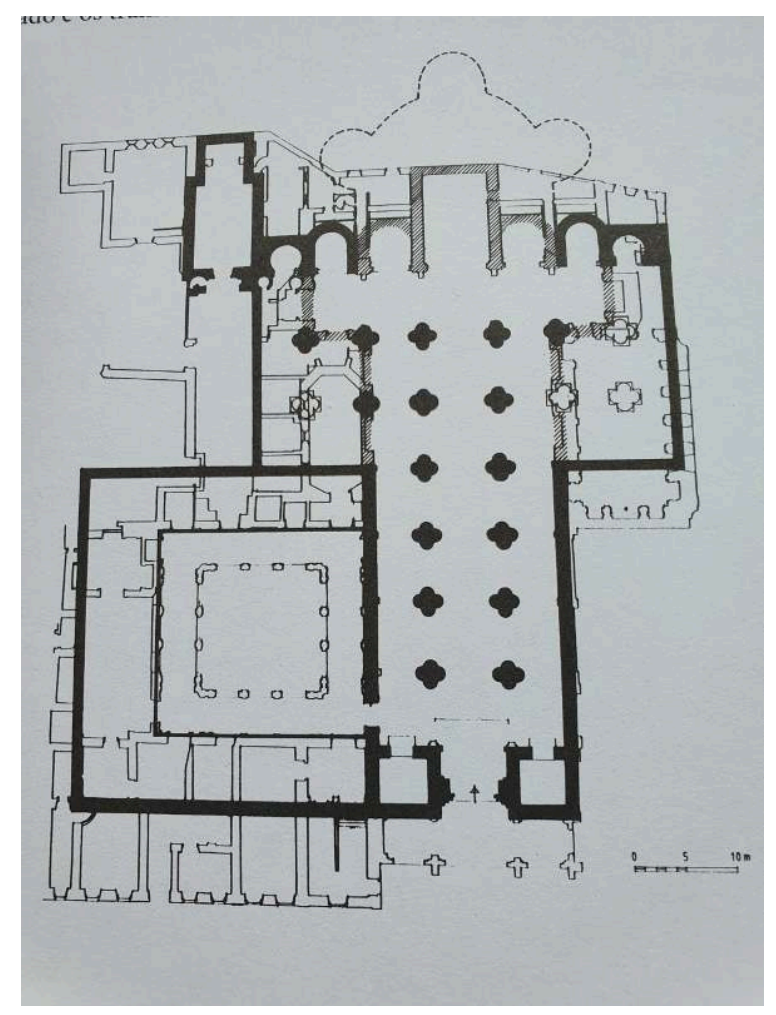

Fig. 3 - Hipótesis de la planta de Braga según REAL, Manuel Luís - "O projecto da Catedral de Braga no século XI e as origens do Românico português", fig. 30, p. 504.

La opinión de Real es seguida por Miranda y Vieira da Silva ${ }^{80} \mathrm{y}$ corroborada por Vieira da Silva y Afonso ${ }^{81}$, quienes, si bien discrepan con respecto al mencionado autor en la consideración de dicho proyecto como un centro de peregrinación en competencia directa con Compostela, coinciden con el hecho de que el proyecto inicial fue desarrollado por el obispo don Pedro y tendría un transepto de tres naves ${ }^{82}$ (Fig. 4).

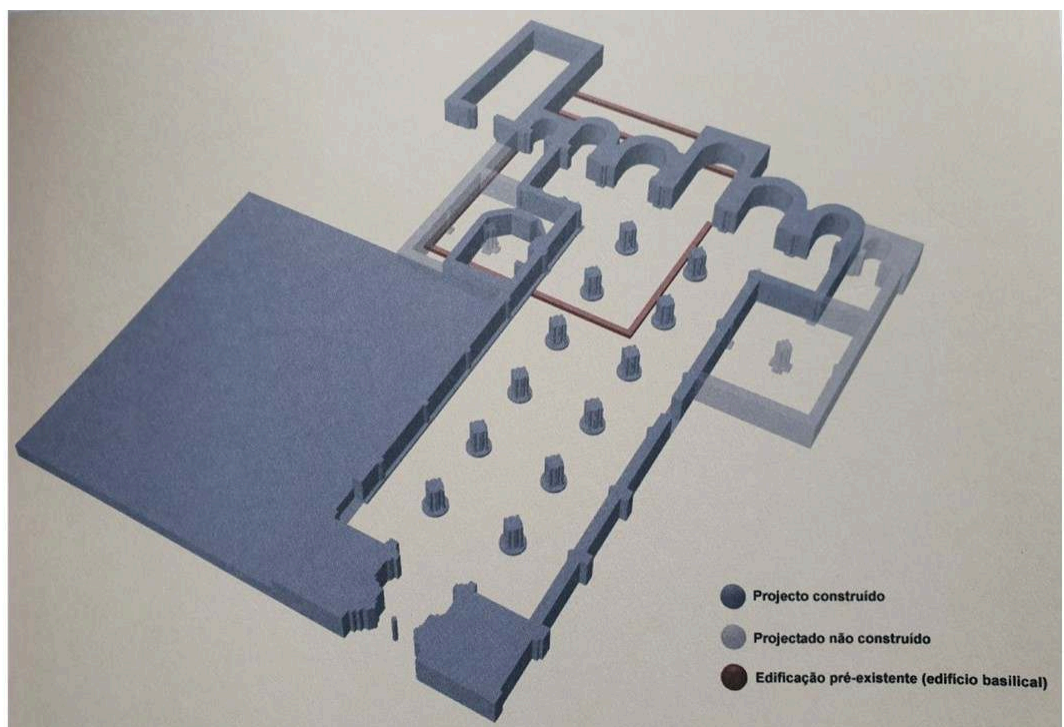

Fig. 4 - Reconstrucción de los primeros proyectos de la catedral de Braga. Fonte: SILVA, José Custódio Vieira da; AFONSO, Luís Urbano - "A arquitectura e a produção artística", estampa 2, p.34.

Por el contrario, no se puede ocultar que otros autores discrepan de este planteamiento. Es el caso de Ferreira de Almeida, quien ya en su tesis doctoral había 
considerado inaceptables las propuestas de Lacerda que pretendían una planta con cinco naves y siete capillas en la cabecera ${ }^{83}$; posteriormente señala que no hay ninguna razón válida para defender esta posición, ni desde el punto de vista arqueológico ni histórico ${ }^{84}$. Botelho ${ }^{85}$ concuerda con un inicio en época de don Pedro, como demostraría la inscripción existente en parte de un dintel, que reza: Huius $E$ (cclesie) (?) ${ }^{86}$. Sin embargo, atribuye erróneamente el gran proyecto a Paio Mendes (1118-1138), siguiendo las opiniones de Lacerda y Real, pues ella misma se contradice al indicar: "Este projecto do século XI contemplaria uma igreja basilical de cinco naves e com transepto formado por três, sobre o qual assentaria uma tribuna" ${ }^{87}$; no obstante, indica que no se puede pasar de una mera conjetura ${ }^{88}$.

Otro aspecto destacado, y que ha planteado hipótesis divergentes tanto en Braga como, sobre todo, en Tui, es la cabecera. En el caso de la catedral de Tui, como ya se ha señalado en otras ocasiones ${ }^{89}$, consideramos que la cabecera no parece haber tenido girola, debido a la falta de espacio, opinión ya expresada por Bango ${ }^{90}$, y que Vila refuta ${ }^{91}$, pero también por la falta de recursos con los que contaba la sede para una empresa de tal envergadura y la comparación con otros ejemplos de la época. Pese a que la opinión más generalizada consideraba la existencia de tres ábsides ${ }^{92}$, dedicados a santa María, Santiago y san Pedro, advocaciones que se conservan en la actualidad, la posibilidad de cinco, hipótesis apuntada ya por Chamoso ${ }^{93}$ e Iglesias Almeida ${ }^{94}$, está avalada por la documentación conservada en el archivo catedralicio y la propia arquitectura. Entre la primera está el testamento otorgado en 1264 por Fernán Yáñez, arcediano de Tui, en donde se indica: "Iten mandat ad cooperiendum ousiam sancte Marie virginis et sancti Petri et sancti Iacobi de petra CL morabetinos [...] Iten mandat ad vitrandas fenestras de ousia sancte Marie et sancti Iacobi et sancti Petri et sancti Vincentii ecclesie tudense C morabetinos"95. Se puede comprobar que se refiere a un ábside dedicado san Vicente. Asimismo, en 1385, en las últimas disposiciones de Johan Mouro, pedreyro natural de Valença, que se manda enterrar en la sepultura que le otorgó el cabildo en el cementerio de Santa María de la sede de Tui, se señala: "Yten mando aas cofrarias de San Pedro et de San Viçente a cada una dez maravedís et que me veñan fazer honrra e no enterramento como seu confrade et aja parte delas como confrade" ${ }^{96}$; asimismo dona el dinero de la venta de determinados bienes para la obras de la Iglesia de Tui ${ }^{97}$. No creemos casual que los titulares de dichas cofradías se puedan corresponder con los de dos capillas absidales. Por otro lado, en relación con el carácter transfronterizo de esta ciudad ${ }^{98}$, durante buena parte del siglo XII los talleres tudenses irradiaron al norte y sur del Miño, por lo que era normal que un pedrero natural de un lugar tan próximo, aunque por entonces ya se encontraba en otro país, se entierre en el cementerio de su sede episcopal, en la que quizá hubiese trabajado como pedrero.

La noticia de una quinta capilla la proporciona un documento del notario Alonso Fernández emitido en 1461, sobre la sepultura de Álvaro de Porto; en él se concede permiso para pintar y reparar la capilla de Santa Eufemia, así como cubrir de madera y teja su torre, antes de que empeoren las ya malas condiciones en que se encuentra su tejado ${ }^{99}$. Dado que el documento señala que la capilla de Santa Eufemia posee un tejado, podemos pensar que no se situaría en el interior de la catedral, sino que sobresaldría, resultando muy probable que se tratase de una capilla absidal; asimismo el mal estado en el que se encontraba puede indicar que se trata de una construcción antigua.

Por lo que respecta a los restos que todavía se conservan en una estructura que ha sufrido numerosas modificaciones, se pueden apreciar, en primer lugar, en la 
configuración de los tramos del transepto que puede confirmar la posibilidad de la existencia de cinco ábsides (Fig. 1): desde el crucero, que posee la amplitud de la nave mayor, existen tres tramos hacia el norte y otros tantos hacia el sur; el primero es la continuación de las naves laterales, constituyendo casi un cuadrado, mientras que el segundo posee menor amplitud, dando lugar a un espacio rectangular; finalmente, el último tramo vuelve a resultar más amplio, sin llegar a la longitud del primero. Ello obliga a peraltar considerablemente los arcos de medio punto, tal como se puede observar claramente en el interior (Fig. 5).

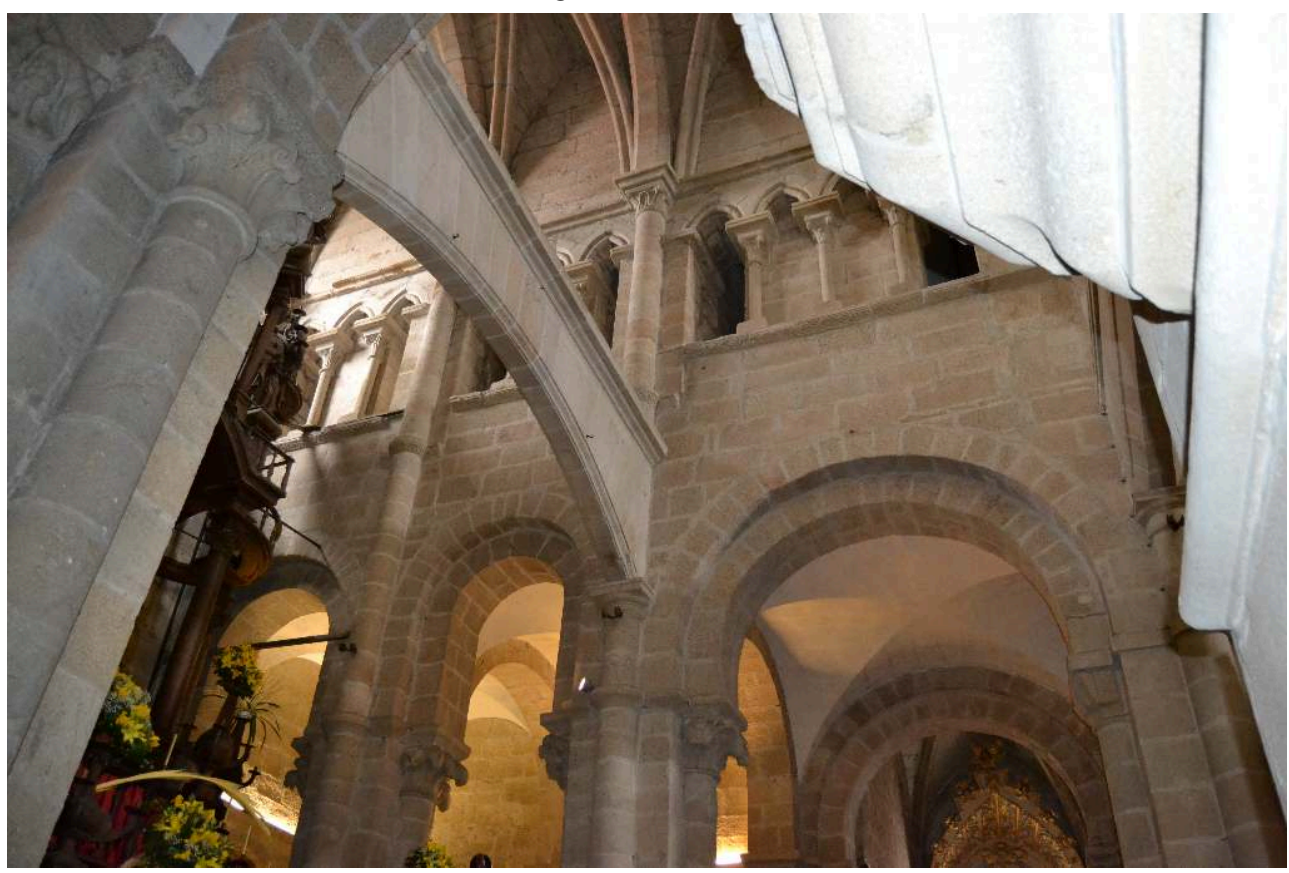

FIg. 5 - INTERIOR DEL TRANSEPTO LA CATEDRAL DE TUI. FUENTE: FOTO DEL AUTOR.

En segundo lugar, si se observa detenidamente el muro oriental de acceso a los ábsides, se puede apreciar, comenzando por el extremo noreste: en el primer tramo un gran arco tapiado sobre el que, con posterioridad, se abrió una ventana, hoy también tapiada; en el tramo siguiente del transepto norte se abre una ventana que todavía se conserva en buen estado (Fig. 6); a continuación, se halla el acceso al ábside de Santiago, cuyos arcos de ingreso corresponden a la fábrica románica.

En el brazo sur, simétricamente, se encuentra el acceso al ábside de San Pedro; en el tramo siguiente habría habido otra ventana, como dejan entrever los restos de dovelas en el muro; finalmente, el arco de acceso a la actual capilla de San Telmo (Fig. 7) se correspondería con el de la quinta capilla. 


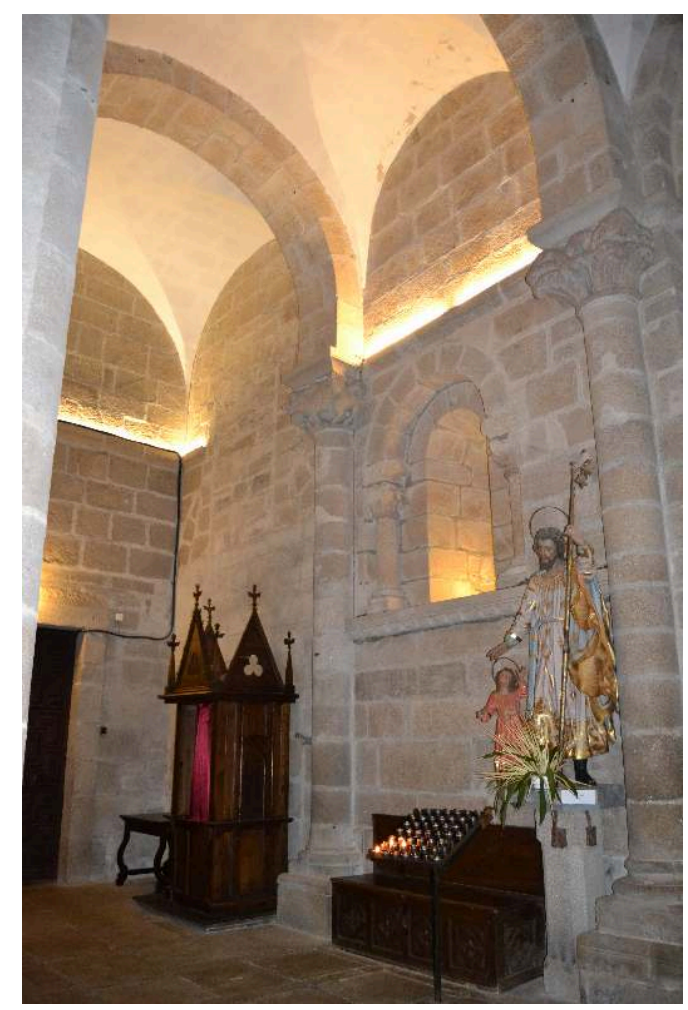

Fig. 6 - RESTOS DE CABECERA ROMÁNICA dE LA CATEDRAL dE TUI. BRAZO NORTE. FUENTE: FOTO dEL AUTOR.

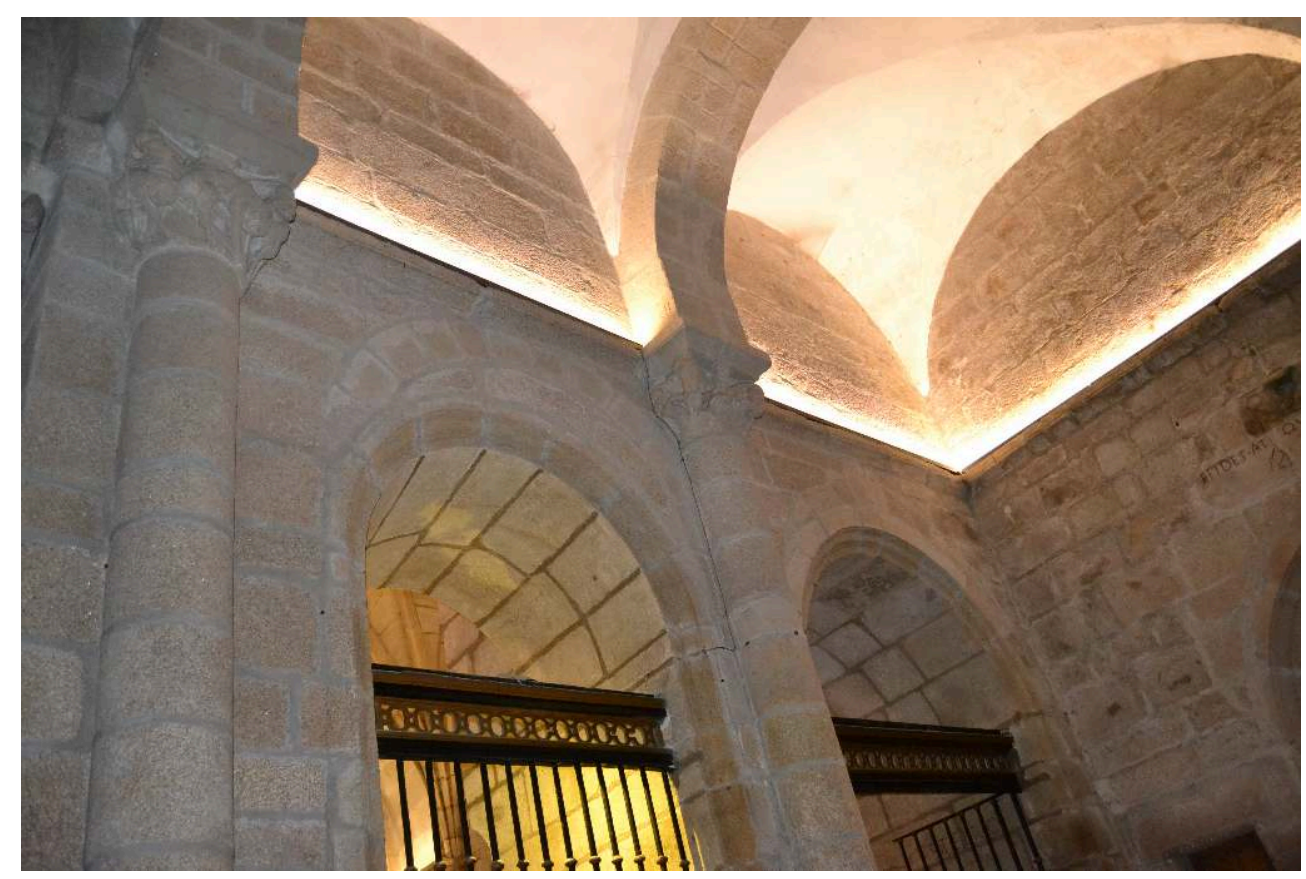

Fig. 7 - Restos de cabecera románica de la catedral de Tui. Brazo sur. Fuente: foto del autor.

30 Junto a ello, la estructura absidal propuesta podría verse corroborada por un contrafuerte existente entre los arcos de ingreso a la citada capilla, visible desde su interior, testigo de la separación entre el paño mural con la ventana y el último ábside (Fig. 8). 

ábsides. Para algunos autores serían rectos ${ }^{100}$, mientras que otros, apoyándose en el cambio que se quiso dar a la iglesia de San Bartolomé de Rebordáns (Tui) consideran que debieron ser semicirculares ${ }^{101}$. Es probable que se tratase de esta última solución, dada su similitud con otros ejemplos que se abordarán posteriormente.

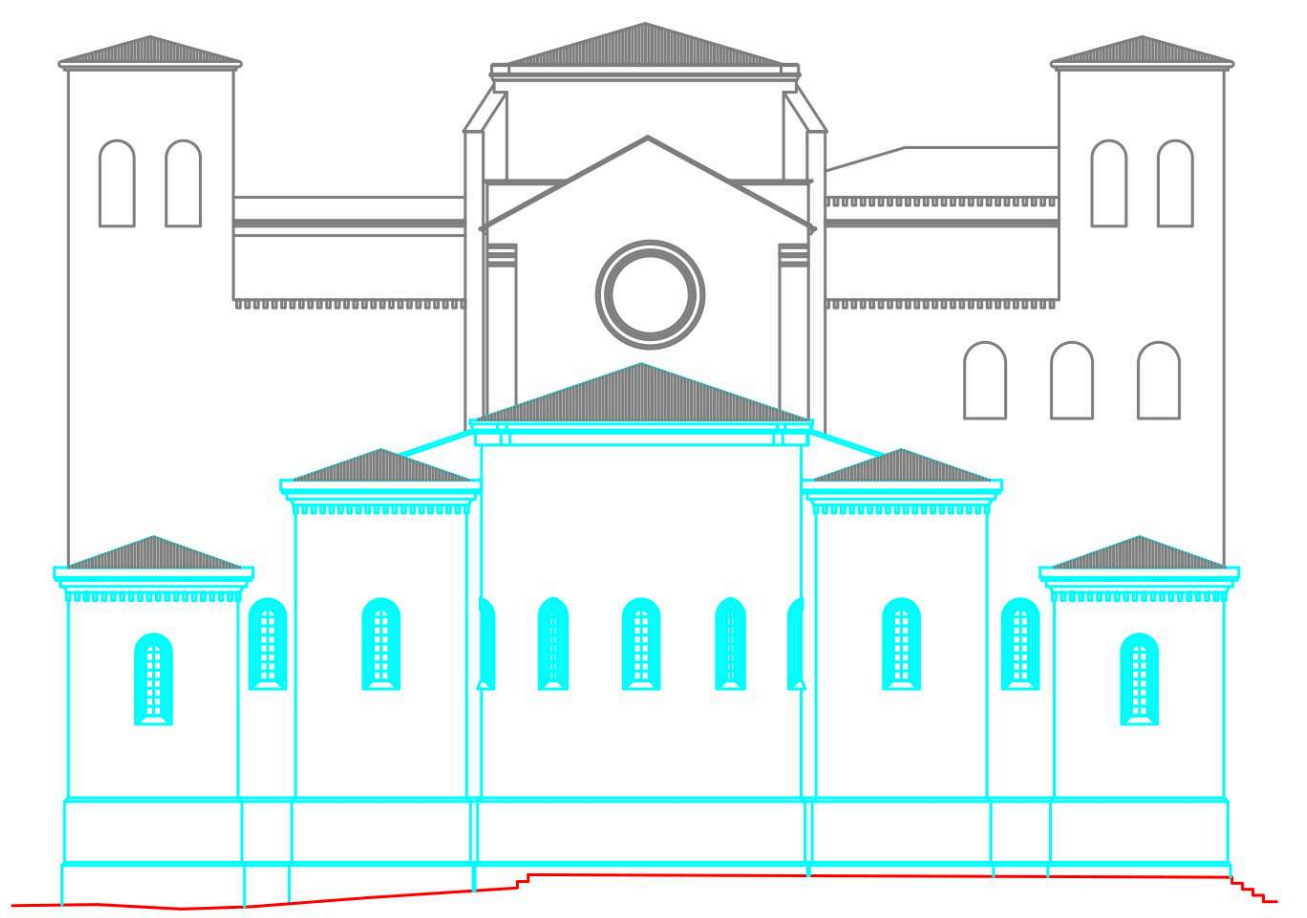

Fig. 8 - ReCONSTRucción de LA CABECERA EXTERIOR DE LA CATEDRAL MEdieVAL de tUI. PLAN DIRECTOR DE LA CATEDRAL DE TUI 200, IAgO SEARA MORALES.

Un paso más sería la ubicación de ambos absidiolos. Iglesias Almeida supone que el dedicado a san Vicente se encontraría en el lugar de la actual sacristía, en el lado de la Epístola, mientras que, por simetría, el de Santa Eufemia se correspondería con la posterior capilla de las Reliquias ${ }^{102}$. Por lo que respecta a las advocaciones de las capillas de la cabecera, la central, de santa María, se dedica a la patrona de la catedral, mientras que las contiguas, de Santiago y san Pedro, hacia el norte y sur respectivamente, se consagran a dos apóstoles. Finalmente, las de san Vicente y santa Eufemia, poseen advocaciones de mártires, ambos muy vinculados al área tudense. Realmente, fueron advocaciones muy repetidas en toda la diócesis y siguen una disposición frecuente en otras catedrales. La ubicación de Santiago en el lado del Evangelio no resulta extraña teniendo en cuenta la posición de Tui en el camino "portugués" de peregrinación a Compostela, cuestión relevante a la hora de la comparación con Braga.

En lo que atañe a la catedral de Braga, la reconstrucción de la cabecera inicial también es fruto de diversas hipótesis. Según Aarão de Lacerda (Fig. 3), se abrirían absidiolos al transepto y girola, siguiendo un trazado benedictino que no llegó a completarse pues fue modificado y disminuido; entre sus vestigios estaría una capilla de planta de arco peraltado que vincula con el mundo cluniacense ${ }^{103}$. Ferreira de Almeida, por su parte, considera que la primera catedral de Braga que consagró don Pedro estaría más próxima al primer románico, pues cree que dicho obispo todavía estaría vinculado al 
llamado rito "mozárabe", así como ese primer proyecto lo estaría a la tradición artística altomedieval ${ }^{104}$. Sin embargo, cree que el ábside de planta en herradura, que hoy está en el exterior de la catedral, pertenecería al primitivo proyecto románico que don Soeiro Mendes (sic) habría iniciado ca.1128 cuando don Alfonso Henríquez le concedió licencia para acuñar moneda ${ }^{105}$. En su opinión la iglesia que don Pedro había consagrado sería protorrománica y tendría un ábside cuadrangular - de raigambre astur -, como demostraría la donación de un frontal de 5,24 metros de altura en 1088 por parte de doña Guntroda Núñez, para cubrir la pared del fondo ${ }^{106}$. Por su parte Real considera que el cuerpo central tendría tres naves, que se prolongan en cuatro tramos, habiéndose rematado la nave central por un quinto tramo, mientras las laterales serían dos torres. En consonancia con ello y dado el momento en el que surge la obra, el proyecto se había concebido como una basílica con deambulatorio y capillas radiales ${ }^{107}$, siguiendo, en su opinión, un modelo típico de las iglesias de peregrinación ${ }^{108}$. En el lado norte, en el exterior de la basílica actual, existe un absidiolo románico de factura antigua ${ }^{109}$, que en la Baja Edad Media se dedicó a Nuestra Señora de Loreto ${ }^{110}$. Posee dos características destacables: el remate exterior es recto, mientras la planta es en herradura, lo que le confiere un aspecto primitivo. Por lo que respecta a su alzado, el arco es de medio punto, peraltado, en correspondencia con las grandes catedrales del último tercio del siglo XI, y cuya cronología temprana se vería confirmada por la decoración de los frisos y la tipología de los capiteles y las basas ${ }^{111}$. De hecho, en su opinión, la consagración del altar mayor el 28 de agosto de 1089 revelaría que en esa fecha la obra estaría ya avanzada ${ }^{112}$. Sin embargo, este autor matiza cuál sería la función del frontal donado por doña Guntroda Nunes, que no se dispondría en el fondo del ábside central, sino que se colocaría en el arco triunfal, como remate digno para el momento de la consagración del altar ${ }^{113}$. La opinión de Vieira da Silva y Afonso sigue, en buena medida la de Real, considerando que se trata de una iglesia plenamente integrada en la cultura artística europea de la época, tanto por el formulario arquitectónico como por la escala proyectada, aun cuando existirían algunos arcaísmos ibéricos: con tres naves estructuradas en cuatro tramos, un transepto saliente de tres naves distribuidas en siete tramos y una cabecera con un ábside semicircular, seguida por un deambulatorio con capillas radiantes ${ }^{114}$. Sin embargo, en la planta que proporciona esta obra (Fig. 3), se omite la girola y se presenta una cabecera con siete ábsides, el central y los absidiolos de los extremos de estructura recta en el exterior ${ }^{115}$, considerando el gran transepto como proyecto no construido.

Si consideramos aceptable que el proyecto de don Pedro contaba con un transepto de tres naves, lo que se ha observado a través de la bibliografía es que no existe un acuerdo con respecto a cuál es la causa, si bien entre las corrientes de opinión Santiago de Compostela desempeña un papel relevante. Real considera que el ambicioso proyecto para Braga tenía la intención de crear un importante centro de peregrinación en competencia con Compostela ${ }^{116}$; por su parte Vieira da Silva y Afonso no consideran que se intentase de establecer una competición directa con Santiago, "tarefa perfeitamente quimérica", sino de captar una parte significativa de los peregrinos que atravesaban la península de modo que realizasen una breve inflexión hacia el sur, antes o después de la visita al túmulo de Santiago, para venerar las reliquias bracarenses, de las que destacaban las de san Fructuoso, san Silvestre, san Cucufate, santa Susana y san Víctor ${ }^{117}$. 

establecer un nuevo paralelo para la catedral de Tui, cuya planta resulta poco equilibrada como estructura de cruz latina, pues su brazo mayor es muy corto, mientras su cabecera es muy desarrollada. En este sentido sería más próxima al modelo de Santa Fe de Conques ${ }^{118}$ al igual que Braga.

Si bien Real confirma que carecemos de información suficiente con respecto a la primitiva cabecera, concluye que sus similitudes con dicha iglesia son muy estrechas, tanto en la planimetría como en los arcaísmos que evidencian ambas construcciones. Asimismo, el nombramiento de Geraldo, consagrado en Sahagún en 1096, el cual era originario de Cahors ${ }^{119}$, explicaría que por tierra natal, muy próxima a Rouerge, donde se encontraba Conques, así como su formación en Moissac y su estancia en Toulouse, conociese los ejemplos franceses ${ }^{120}$. Sin embargo, se impone una matización con respecto a la vinculación de las girolas con la afluencia de peregrinos: durante mucho tiempo las iglesias de Santa Fe de Conques, San Martín de Tours, San Marcial de Limoges, San Saturnino de Toulouse y Santiago de Compostela ${ }^{121}$, fueron catalogadas como "iglesias de peregrinación". Bango ${ }^{122}$ y Brenk ${ }^{123}$ rebatieron dicha "etiqueta", pues preciso relacionar las cabeceras con girola con usos litúrgicos más que con el tránsito de los peregrinos, como ha insistido Carrero ${ }^{124}$. Además, no poseen toda la misma función pues hay dos colegiatas (Tours y Toulouse), dos abaciales benedictinas (Limoges y Conques) y una catedral (Santiago). Por ello consideramos que no existe la necesidad de vincular una tipología con girola con el carácter de iglesia que ha de acoger numerosos peregrinos.

38 A pesar de ello, queremos destacar que existen semejanzas entre las estructuras de Santa Fe de Conques y las catedrales de Tui y Braga, y que no se hallan en la catedral de Santiago: con respecto a la tudense (Fig. 1), el transepto cuenta solo con siete tramos, sobre ellos existe una tribuna, la cual posee un ándito estrecho entre el lado este y el oeste, al igual que ocurre en Conques; en los extremos norte y sur de Braga no existe una nave transversal, por lo que estaríamos de nuevo ante una estructura semejante con los otros dos ejemplos citados.

Al margen de lo que pudo ser la cabecera inicial, el proyecto bracarense cambia en el siglo XII ${ }^{125}$. Existen una serie de fuentes que hacen pensar en una destrucción violenta de la obra iniciada por don Pedro, tras la muerte de Geraldo ${ }^{126}$, hacia 1109-1110. En el diploma otorgado por doña Teresa el 29 de octubre de 1110 se confirman los privilegios de la sede debido a los malos tratos que le habían causado sus hombres: "os meus maiorinos, não temendo o santuário de Deus, entraram armados na igreja e no claustro e fizeram arruinar a importante igreja bracarense" ${ }^{127}$. Por su parte las excavaciones de la calle Nossa Senhora do Leite mostrarían una capa importante de material de demolición ${ }^{128}$, en tanto que Fontes, Lemos y Cruz consideran la "existencia de um primeiro projecto de maior amplitude, mas, par outro lado, a ausencia de evidencias arqueológicas relacionadas com um transepto de três naves poderá significar que a sua construção nunca terá passado do projecto" ${ }^{129}$. Fue el arzobispo Paio Mendes el que iniciaría la reconstrucción de la catedral, obteniendo en 1128 el privilegio para acuñar moneda, con el objeto de proseguir la construcción de la basílica. En 1131 intenta reactivar el culto en la capilla mayor reconstruida y en 1135 conocemos el nombre del arquitecto de la obra: Nuno Pais ${ }^{130}$. Sin embargo, Real niega la existencia de un terremoto en 1135 que hubiese destruido las torres de la sede ${ }^{131}$. Lo que plantea es que este arzobispo optaría por una solución más modesta de cabecera, con cinco capillas 
abiertas hacia un transepto de una sola nave, mientras en cuerpo de la iglesia se ampliaría hasta siete tramos. Sin embargo, considera que el remate de la capilla mayor sería recto - ya que en las excavaciones no se han encontrado restos de ábside semicircular -, al igual que los absidiolos más extremos ${ }^{132}$ (Fig. 3).

Según se ha señalado en la primera parte del trabajo, los contactos entre la sede bracarense y la tudense son muy estrechos ${ }^{133}$, no pudiendo olvidar el carácter de sufragánea de Tui con respecto a Braga. Por otro lado, la dedicación del altar mayor de Braga, el 28 de agosto de 1089, estuvo presidida por don Bernardo de Toledo, con la participación de los obispos Pedro de Braga, Gonzalo de Dumio, Auderico de Tui y Pedro de Ourense $\mathrm{e}^{134}$ (tabla 1). Todos estos contactos podrían explicar una posible relación entre las plantas de la catedral de Braga y la de Tui: el transepto triple del primer proyecto, y la cabecera de cinco ábsides del segundo. Con todo carecemos de fuentes documentales y arqueológicas que permitan afirmarlo de manera fehaciente, por lo que solo se trata de plantear una hipótesis diferente de todas las que hasta ahora se han propuesto.

41 Para Tui se pueden encontrar parelelos en iglesias francesas y españolas, entre ellas las cistercienses de Meira y $\mathrm{Oia}^{135}$, las cuales poseen los ábsides rectos al interior y al exterior. Realmente entre esta última y la catedral de Tui los contactos son muy importantes, llegando a realizarse donaciones mutuas ${ }^{136}$, cuando en 1145 , como respuesta a la generosidad del obispo Pelayo, los monjes entreguen dos marcos de plata "in opus Ecclesiae S. Mariae faciendum"137. La influencia del cister será patente en partes de la propia obra tudense, como el claustro, e incluso es posible pensar en un intercambio de maestros entre ambas ${ }^{138}$. Pero también hay que señalar los contactos del monasterio de Oia con Portugal donde poseía numerosos bienes ${ }^{139}$.

El tipo de cabecera de cinco ábsides escalonados también existió en otra catedral gallega, sufragánea de Braga: la de Ourense. Pita considera que tendría cinco ábsides semicirculares $^{140}$ (Fig. 9).

Carro recoge que en el siglo XII la capilla central ourensana estaba dedicada a la Virgen, como en el caso tudense ${ }^{141}$; sin embargo, Carrero se apoya en la documentación para recoger las advocaciones de las capillas absidales de la sede auriense ${ }^{142}$ (Fig. 10).

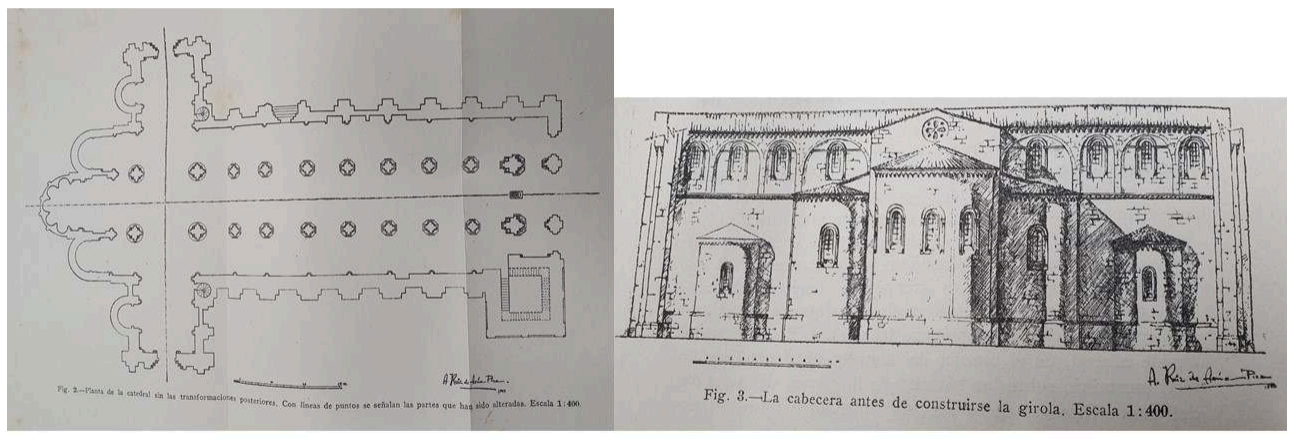

Fig. 9 - Planta y cabecera de la catedral de Ourense. Fuente: PITA ANDRADE, José Manuel - La construcción de la catedral, anexo IX, p.40. 


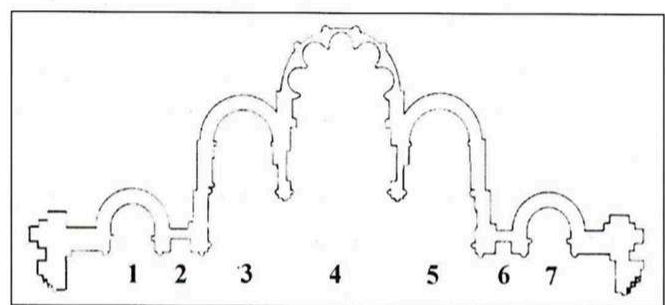

Planta de la cabecera de la catedral con las advocaciones originales. 1. Santa Marina. 2. Santa Margarita. 3. San Eleuterio. 4. San Martín. 5 Santa Eufemia. 6. Santa Catalina. 7. San Andrés.

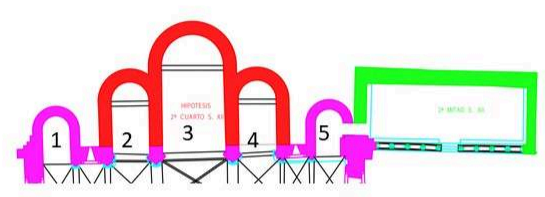

Planta de la cabecera de la catedral de Tui con las advocaciones originales.

Fig. 10 - Cabecera y advocaciones de la catedral de Ourense. Fuente: CARRERO SANTAMARÍA, Eduardo - "De la catedral medieval de Ourense y sus inmediaciones. Nuevas hipótesis sobre viejas teorías", fig. 5, p. 29. Comparación con las tudenses según Cendón Fernández.

A la hora de buscar posibles paralelos para aquellos edificios medievales que han sufrido numerosas transformaciones, y de los cuales carecemos de documentos que permitan afirmar fehacientemente su proceso constructivo, se impone un análisis de tipo comparativo, de posibles transferencias artísticas, que, en ocasiones, no permite ir más allá de un simple planteamiento hipotético. En la catedral de Tui, el obispo Pedro Beltrán realiza una reforma total en la cabecera, entre 1495 y 1499, que supuso la total transformación de lo existente para construir, tal como hoy se conserva, una cabecera triple y plana. Añadidos posteriores como la capilla de San Telmo o la actual sacristía, han ido enmascarando todavía más las trazas románicas, obligándonos a rastrear en busca de pistas que nos permitan una reconstrucción del estado original de la catedral tudense. Por su parte, la catedral de Braga todavía posee una historia más compleja ya que el primer proyecto románico no ha ido más allá de una aspiración y su 
reconstrucción, aunque bien fundamentada por Real, precisa de nuevas aproximaciones, en espacial de la arqueología con sus técnicas más avanzadas.

La comparación entre las planimetrías de ambas catedrales durante el medievo, así como otras semejantes, nos podría llevar a concluir que el transepto tudense, tan desarrollado, con tres naves, que solo se comparó hasta ahora con el de la catedral de Santiago, podría asemejarse al proyectado para la catedral de Braga bajo el episcopado de don Pedro. Teniendo en cuenta el proceso cronoconstructivo de ambos edificios, se habría iniciado antes el bracarense, mientras que el de Tui, datable hacia mediados del siglo XII, pudo tomar como modelo el de su metrópoli.

Otra cuestión sería que el tamaño del proyecto y la forma del transepto, en ambos casos, pudiera asemejarse al de Santa Fe de Conques, sin que se pueda afirmarse de qué modo pudo haber llegado ese modelo, salvo la relación que Geraldo poseía con el entorno cercano a Aveyron. La insistencia en una cabecera con girola y capillas radiales ha partido de la consideración de dicha tipología como la característica de las iglesias de peregrinación, cuestión hoy descartada frente al papel que posee la liturgia y que resulta común a muchos centros de los que carecemos un refrendo como importantes centros de peregrinación. Por lo que atañe a la liturgia es muy importante el papel que en este momento poseía la implantación del rito romano. Como se ha indicado, existían ciertos recelos con respecto a don Pedro al que se consideraba continuador de la tradición mal llamada "moçárabe", mientras que Geraldo encarnaría los postulados de los centros que se encontraban en la vanguardia de la difusión del rito romano. En el caso tudense, consideramos que el inicio de la catedral románica, tras su destrucción posterior a las invasiones musulmanas $\mathrm{y}$, sobre todo, germánicas, que la obliga a permanecer en el monasterio de San Bartolomé tras la restauración de la sede, tendrá que ver con la reorganización de la canónica por parte del obispo Pelayo hacia 1137, para lo cual solicitará canónigos de la Santa Cruz de Coimbra; se trata de una actividad directamente relacionada con la reforma gregoriana.

50 En relación con el tipo de cabecera, aunque la primitiva de Braga hubiese tenido girola, a partir del segundo cuarto del siglo XII, fecha en la que situamos los inicios de la cabecera tudense, va a estar formada por cinco capillas. Si bien en el caso tudense consideramos que serían semicirculares, en el de Braga podría haber una alternancia entre rectangulares y semicirculares. Existen modelos cercanos que siguen esta misma configuración, en especial en catedrales que eran sufragáneas de Braga como es el caso de Ourense o Lamego. Otros edificios como Santa María del Azogue en Benavente, se consideran seguidores del ejemplo auriense.

51 La necesidad de nuevas campañas arqueológicas, unida a nuevos enfoques en el tratamiento de estos edificios como la relación con la liturgia, las advocaciones y la búsqueda de nuevos apoyos documentales, podrían permitir en un futuro profundizar en lo que en este caso es solo una primera aproximación. 


\section{BIBLIOGRAFÍA}

Fuentes manuscritas

Tui, Archivo Catedral de Tui, Testamento del arcediano de Tui Fernandus Johannis, Becerro I, fol. 131v.-132r.; ap. doc. $\mathrm{n}^{\mathrm{o}}$ I, 20 del Mayo del 1264.

Tui, Archivo Catedral de Tui, Testamento de Johan Mouro, pedrero, natural de Valença, Becerro I, fols. 58v.-59r, 5 del Octubre del 1385.

Tui, Archivo Catedral de Tui, El cabildo de Tui concede permiso a Alvaro de Porto para que arregle la capilla de Santa Eufemia y haga allí su sepultura. Protocolo del notario Alonso Fernández, 19 del junio del 1461.

Fuentes impresas

ÁVILA Y LA CUEVA, Francisco - Historia civil y eclesiástica de la ciudad de Tuy y su obispado, Archivo de la Catedral de Tui, 4 tomos, 1852. Ed. facs. Santiago de Compostela: Consello da Cultura Galega, 1995.

FLÓREZ, Henrique - España Sagrada. Tomo XXII. Madrid: Antonio Marín, 1767. Ed. facs. Lugo: Alvarellos, 1992.

VÁZQUEZ DE PARGA, Luis; LACARRA, José Mª; URÍA RIU, Juan - Las peregrinaciones a Santiago de Compostela. Pamplona: Iberdrola, Gobierno de Navarra, 1992, 3 vols. (ed. facs. de la realizada en 1948 por el C.S.I.C.)

Estudios

ALMEIDA, Carlos Alberto Ferreira de - Arquitectura românica de entre-Douro-e-Minho. 2 vols. Porto: 1978. Tese de Doutoramento.

ALMEIDA, Carlos Alberto Ferreira de - História da Arte em Portugal. Vol. III. O Românico. Lisboa: Alfa, 1986.

ALMEIDA, Carlos Alberto Ferreira de - "Influências francesas na Arte românica portuguesa". In Histoire du Portugal. Histoire europeène. Paris: FCG, 1987, pp. 27-36.

ALMEIDA, Carlos Alberto Ferreira de - História da Arte em Portugal. o Românico. Lisboa: Editorial Presença, 2001.

AMARAL, Luís Carlos - Formação e desenvolvimento do domínio da diocese de Braga no período da reconquista (século X-1137). Porto: Universidade do Porto, 2007. Tese de Doutoramento.

ANDRADE, Amélia Aguiar - Vilas, poder régio e fronteira: o exemplo do Entre Lima e Minho. Lisboa: Universidade Nova de Lisboa, 1994. Tese de Doutoramento.

ANDRADE, Amélia Aguiar - "Entre Lima e Minho e Galiza na Idade Média: uma relaçâo de amor e odio". In Carlos Alberto Ferreira de Almeida In Memoriam. Porto: Faculdade de Letras da Universidade do Porto, 1999, pp. 77-91.

ANDRADE CERNADAS, José M. - "Fuentes documentales para el estudio del Rey García de Galicia”. Minius VI (1997), pp. 41-49.

ANÓNIMO - “Catedrales. La catedral de Tuy”. In OTERO PEDRAYO, Ramón (dir.) - Gran enciclopedia gallega. Tomo VI. Vitoria: Silverio Cañada, 1974. 
ARMAS CASTRO José; LÓPEZ ALSINA, Fernando - "La ciudad de Tui en la Edad Media". In SEARA MORALES, Iago (coord.) - La catedral de Tui desde su plan director. Santiago de Compostela: Xunta de Galicia, 2015, pp. 69-76.

BANGO TORVISO, Isidro G. - Arquitectura románica en Pontevedra. La Coruña: Fundación Pedro Barrié de la Maza, 1979.

BANGO TORVISO, Isidro G. - "Las llamadas iglesias de peregrinación o el arquetipo de un estilo". In CARBALLO-CALERO, M. ' Victoria (ed.) - El camino de Santiago, camino de las estrellas. Santiago de Compostela: Fundación Caixa Galicia, 1994, pp. 233-284.

BARREIROS, Manuel Aguiar - A catedral de Santa Maria de Braga. Porto: Marques de Abreu, 1922 (ed. facs.1999).

BARROS GUIMERÁNS, Carlos - “La frontera medieval entre Galicia y Portugal”. Medievalismo 4 (1994), pp. 27-39.

BESSA, Paula - "Arquitectura románica e gótica no Minho". In A Arte no Minho. Braga: Centro de Estudios Lusiadas-Universidade do Minho, 2011, pp. 63-89.

BOTELHO, Maria Leonor - “Sé de Braga”. In PÉREZ GONZÁLEZ, José María (dir.) - Arte Românica em Portugal. Aguilar de Campoo: Fundación Santa María la Real, 2010, pp. 41-52.

BOUZA BREY, Fermín - "Lauda sepulcral de Nausto, obispo de Coimbra". In Estudios sobre la Monarquía Asturiana, XI centenario de Alfonso II el Casto (1942). Oviedo: Consejo Superior de Investigaciones Científicas, Instituto de Estudios Asturianos, 1950 (2 $2^{\mathrm{a}}$ ed. 1971), pp. 275-286.

BRENK, Bea - "Les églises de pèlerinage et le concept de prétention". In BOCK, N. ; KURMANN, P.; ROMANO, S.; SPIESER, J. M. (eds.) - Art, Ceremonial et Liturgie au Moyen Âge. Actes du colloque de 3e Cycle Romand de Lettres Lausanne, Fribourg (2000). Roma: s.e., 2002, pp. 125-139.

CARBAJA SOBRAL, José - Los concilios de Braga en los siglos VI y VII, reflejo de la vida en la Gallaecia de la época. Porriño: Paz, 1999.

CARRERO SANTAMARÍA, Eduardo - "De la catedral medieval de Ourense y sus inmediaciones. Nuevas hipótesis sobre viejas teorías". Porta da aira: revista de historia del arte orensano 9 (2002), pp. 9-30.

CARRERO SANTAMARÍA, Eduardo - "Le sanctuaire de la cathédrale de Saint-Jacques-deCompostelle à l'épreuve de la liturgie". In ANDRAULT-SCHMITT, Claude (ed.) - Saint-Martial de Limoges: ambition politique et production culturelle (Xe-XIIIe siècles). Limoge: Pulim, 2006, pp. 295-308.

CARRERO SANTAMARÍA, Eduardo - "Retrocapillas, trasaltares y girolas. Liturgia, reliquias y enterramientos de prestigio en la arquitectura medieval”. In FERNÁNDEZ GONZÁLEZ, Etelvina Estudios in memoriam del Prof. Dr. Fernando Galván Freile. Vol. II. León: Universidad de León, 2010, pp. 63-81.

CARRERO SANTAMARÍA, Eduardo - "Comulgar con ruedas de molino. Arquitectura y liturgia medievales o los itinerarios de un desencuentro”. Medievalia 15 (2012), pp. 63-66.

CARRERO SANTAMARÍA, Eduardo - "La Sé medieval de Lamego: vías de aproximación a un conjunto catedralicio desaparecido”. In SARAIVA, Anisio Miguel de Sousa (coord.) - Espaço, Poder e Memória: A Catedral de Lamego, sécs. XII a XX. Lisboa: Universidade Católica Portuguesa. Centro de Estudos de História Religiosa, 2013, pp. 47-78.

CARRERO SANTAMARÍA, Eduardo - "Catedral y liturgia medievales. La definición funcional del espacio y sus usos". In SARAIVA, Anísio Miguel de Sousa; MORUJÃO, Maria do Rosário Barbosa 
(coord.) - Espaços, símbolos e poderes. Liturgia e espaço religioso. Lisboa: Universidade Católica Portuguesa. Centro de Estudos de História Religiosa, 2014, pp. 59-100.

CARRIEDO TEJEDO, Manuel - "Episcopologio tudense, de 911 a 1024". Tui. Museo y Archivo Histórico Diocesano IX (2001), pp. 99-127.

CARRIEDO TEJEDO, Manuel - “Obispos de Ourense, Obispos de Tui y Obispos de Lugo (982-1071)". Diversarum Rerum 12 (2017), pp. 13-52.

CARRO GARCIA, Jesús - Las catedrales gallegas. Buenos Aires: Ediciones Galicia del Centro Gallego de Buenos Aires. 1950.

CASTILLO, Ángel del - "La arquitectura en Galicia”. In Geografía General del Reino de Galicia. Generalidades. Vol. II. La Coruña: Ed. Gallega S.A., 1980.

CENDÓN FERNÁNDEZ, Marta - "Hipótesis sobre la planta medieval de la catedral de Tuy". El Museo de Pontevedra XLVII (1993), pp. 101-122.

CENDÓN FERNÁNDEZ, Marta - "Las etapas constructivas de la catedral medieval de Tuy". Tui. Museo y Archivo Histórico Diocesano VII (1994), pp. 197-212.

CENDÓN FERNÁNDEZ, Marta - La catedral de Tui en época medieval. Pontevedra: Fundación Cultural Rutas del Románico, 1995.

CENDON FERNANDEZ, Marta - "El monasterio de Oia”. In YÁÑEZ NEIRA, Fray Damián (coord..) Monasticon Cisterciense Gallego. Vol. I. León: Edilesa, 2000, pp. 197-223.

CENDÓN FERNÁNDEZ, Marta - "El arte medieval en Tui: la catedral como foco receptor y difusor del románico y del gótico”. In CENDÓN FERNÁNDEZ, Marta y GONZÁLEZ SOUTELO, Silvia (coords.) - Tui: Pasado, presente y futuro. I Congreso de Historia de Tui. Pontevedra: Diputación Provincial, 2004, pp. 121-155.

CENDÓN FERNÁNDEZ, Marta - "La catedral de Tui entre Galicia y Portugal”. In Actas II Congresso Internacional de História da Arte. Coimbra: Almedina, 2005, pp. 727-745.

CENDÓN FERNÁNDEZ, Marta - “Tui. La catedral en el Románico”. In Enciclopedia del Románico en España. Pontevedra. Vol. II. Aguilar de Campoo: Fundación Santa María la Real, Centro de Estudios del Románico, 2012, pp. 1143-1161.

CENDÓN FERNÁNDEZ, Marta - "El conjunto catedralicio en la Edad Media". In SEARA MORALES, Iago (coord.) - La catedral de Tui desde su plan director. Santiago de Compostela: Xunta de Galicia, 2015, pp. 77-95.

CENDÓN FERNÁNDEZ, Marta - "Memoria histórico artística. La Catedral Medieval". In SEARA MORALES, Iago (coord.) - La catedral de Tui desde su plan director. Santiago de Compostela: Xunta de Galicia, 2015. CD que acompaña al libro.

CENDÓN FERNÁNDEZ, Marta - "Una catedral de frontera. Tui y Portugal: afinidades y peculiaridades". In BECEIRO PITA, Isabel (coord.) - La espiritualidad y la configuración de los Reinos Ibéricos (siglos XII-XV). Madrid: Dykinson, 2018, pp. 91-147.

CHAMOSO LAMAS, Manuel - Galicia románica. Madrid: Encuentro, 1979.

CHAMOSO LAMAS, Manuel - Tuy. León: Everest, 1981.

CHICó, Mário Tavares - A arquitectura gótica em Portugal, Lisboa: Livros Horizonte, 1981.

COSMEN ALONSO, M Concepción - "Paisajes artísticos velados. La cabecera románica de la catedral de Sigüenza y la posible difusión del modelo". De Arte 15 (2016), pp. 7-32. 
COSTA, Avelino de Jesus da - Liber Fidei Sanctae Bracarensis Ecclesiae. Braga: Junta Distrital de Braga, 1965, 2 vols.

COSTA, Avelino de Jesus da - "O Bispo D. Pedro e a organização da diocese de Braga". In IX Centenário da Dedicação da Sé de Braga. Congresso Internacional- Actas. Vol. I, Braga: Universidade Católica Portuguesa/ Cabido Metropolitano e Primacial de Braga, 1990, pp. 379-434.

COSTA, Avelino de Jesus - O bispo D. Pedro e a organização da Arquidiocese de Braga $2^{a}$ ed.. Vol. I-II. Braga: Ed. da Irmandade de São Bento da Porta Aberta, 1997.

DIAS, Pedro - História da Arte em Portugal. Vol. 4. O gótico. Lisboa: Alfa, 1986.

DIAS, Pedro - A arquitectura gótica portuguesa. Lisboa: Estampa, 1994.

DÍAZ Y DÍAZ, Manuel C.; VILARIÑO PINTOS, Daría - “La diócesis de Tuy hasta 1100”. In GARCÍA ORO, José (coord.) - Historia de las diócesis españolas. Iglesias de Santiago de Compostela y Tuy-Vigo. Madrid: BAC, 2002.

FERNANDES, Paulo Almeida - "Uma nova arte para um novo reino". In BARROCA, Mário Jorge (Ed.) - No tempo de D. Afonso Henriques: reflexões sobre o primeiro século português. Porto: CITCEM Centro de Investigação Transdisciplinar Cultura, Espaço e Memória, 1997, pp. 91-123.

FERNÁNDEZ RODRÍGUEZ, Manuel - "El monasterio de Santa María de Oya y sus maestros constructores”. Cuadernos de estudios gallegos XI (1957), pp. 219-228.

FERREIRA, João Paulo Martins - “A Nobreza Galego-Portuguesa da Diocese de Tui (915-1381). Teoria e metodología”. In MIRANDA, Flávio; SEQUEIRA, Joana; FARIA, Diogo (coords.) - Incipit 2: Workshops de Estudos Medievais da Universidade de Porto 2011-2012. Porto: Universidade de Porto, 2012, pp. 41-50.

FERREIRA, Manuel Pedro - "Liturgia bracarense. Origens, fontes, posteridade”. In SARAIVA, Anísio Miguel de Sousa; MORUJÃO, Maria do Rosário Barbosa (coord.) - O clero secular medieval e as suas catedrais: novas perspectivas e abordagens. Lisboa: Centro de Estudos de História religiosa, Universidade Católica Portuguesa, 2014, pp. 123-140.

FLÓREZ DÍAZ, Javier - En busca de una frontera entre Galicia y Portugal: Las tierras miñotas en los siglos XI-XII. Santander: Universidad de Cantabria, 2016-2017.

FONTES, Luís; LEMOS, Francisco S.; CRUZ, Mário - “"Mais Velho” que a Sé de Braga. Intervenção arqueológica na catedral bracarense: notícia preliminar”. Cadernos de Arqueologia 14/15 (1997-98), pp. 137-164.

GALINDO ROMEO, Pascual - Tuy en la Baja Edad Media Siglos XII-XV. Madrid: El Noticiero, 1923.

GARCÍA ÁLVAREZ, Rubén - "El diploma de restauración de la sede de Tuy por la infanta Urraca". Cuadernos de Estudios Gallegos 17/52 (1962), pp. 275-292.

GASPAR, Alexandra - “Escavações arqueológicas da rua de № $S^{a}$ do Leite (Braga)”. In IX Centenário da Dedicação da Sé de Braga. Congresso Internacional- Actas. Vol. I. Braga: Universidade Católica Portuguesa / Cabido Metropolitano e Primacial de Braga, 1990, pp. 171-172.

GONZÁLEZ SOUTELO, Silvia - “Arqueología de Tui: el papel del enclave Tude en la Antigüedad”. In CENDÓN FERNÁNDEZ, Marta; GONZÁLEZ SOUTELO, Silvia (coords.) - Tui: pasado, presente y futuro. Pontevedra: Diputación Provincial de Pontevedra, 2004, pp. 35-56.

GONZÁLEZ SOUTELO, Silvia - O Tui antiguo: una aproximación histórica-arqueolóxica. Noia: Toxosoutos, 2007.

GRAF, Gerhard N. - Europa románica. Portugal/2. Vol. XIV. Madrid: Encuentro, 1988. 
GUILLOUËT, Jean-Marie - "Les transferts artistiques: un outil opératoire pour l'histoire de l'art médiéval?". Histoire de l'art : bulletin d'information de l'Institut national d'histoire de l'art publié en collaboration avec l'Association des professeurs d'archéologie et d'histoire de l'art des universités, 64 (avril 2009), pp.17-25.

HIDALGO MUÑOZ, Elena - La Iglesia de Santa María del Azogue de Benavente. Salamanca: Centro de Estudios Benaventanos “Ledo del Pozo”, 1995.

IGLESIAS ALMEIDA, Ernesto - "Los signos lapidarios de la catedral de Tuy en los siglos XII y XIII". Tuy. Museo y archivo histórico diocesano, II (1976), pp. 135-146.

IGLESIAS ALMEIDA, Ernesto; MÉNDEZ CRUCES, Plácido - Evocación histórica de la ciudad de Tuy y sus antiguas rúas. Tui: Xuvia, 1990.

IGLESIAS ALMEIDA, Ernesto - "El camino portugués a Santiago en su paso por Tui". Compostellanum XXXIX/3-4 (jul-dic. 1994), pp. 461-474.

IGLESIAS ALMEIDA, Ernesto - El antiguo obispado de Tui en Portugal. Noia: Toxosoutos, 2009.

LACERDA, Aarão de - História da Arte em Portugal. Vol. I. Porto: Portucalense editora, 1942.

LAMPÉREZ Y ROMEA, Vicente - Historia de la arquitectura cristiana española en la Edad Media. Madrid: Espasa Calpe, 1930.

LÓPEZ ALSINA, Fernando - "La cristalización de Tui como espacio de poder señorial entre 1095 y 1157”. In CENDÓN FERNÁNDEZ, Marta; GONZÁLEZ SOUTELO, Silvia (coords.) - Tui: Pasado, presente y futuro. I Congreso de Historia de Tui. Pontevedra: Diputación Provincial, 2004, pp. 57-95.

LÓPEZ FERREIRO, Antonio - Historia de la S.A.M.I. de Santiago de Compostela. T. II. Santiago de Compostela: Imp. y enc. del Seminario Conciliar Central, 1899.

LUCAS ÁLVAREZ, Manuel - Tumbo A de la catedral de Santiago. Sada, A Coruña: Ediciós do Castro, 1998.

MANSILLA, Demetrio - "Restauración de las sufragáneas de Braga a través de la reconquista". Revista Portuguesa de História 6 (1955), pp. 117-148.

MANSO PORTO, Carmen - "Reflexiones sobre la catedral románica y gótica de Santa María de Tui”. Abrente: Boletín de la Real Academia Gallega de Bellas Artes de Nuestra Señora del Rosario (2012), pp. 75-126.

MANSO PORTO, Carmen - “Consideraciones sobre la organización de la capilla mayor y otros espacios devocionales de la catedral de Tui”. Abrente 45 (2013), pp. 153-182.

MARQUES, José - “As doações dos condes portucalenses e de D. Afonso Henriques à Igreja”. In Actas do $2^{\circ}$ Congresso Histórico de Guimarães. Vol. 5. Guimarães: Câmara Municipal de Guimarães; Universidade do Minho, 1996, pp. 326-347.

MARQUES, José - “Las diócesis portuguesas hasta 1150”. In LÓPEZ ALSINA, Fernando (ed.) - El Papado, la Iglesia Leonesa y la Basílica de Santiago a finales del siglo XI. Santiago: Consorcio de Santiago, 1999, pp. 177-214.

MARQUES, José - "Senhorio de Braga e arcebispos da independência". Bracara Augusta 49 (2000), pp. 127-174.

MARQUES, José - “As dioceses portuguesas até 1150”. Biblos 78 (2002), pp. 7-59.

MARQUES, José - “D. Teresa num tempo de mudança”. Bracara Augusta 51:106 (119) (2003), pp. 5-25. 
MARQUES, José - “A Fronteira do Minho. Espaço de Convivência Galaico-Minhota, na Idade Média". In Estudos em Homenagem a Luís António de Oliveira Ramos. Vol. II. Porto: Faculdade de Letras da Universidade do Porto, 2004, pp. 697-712.

MARQUES, José - “A Igreja no tempo de D. Afonso Henriques. Alguns aspetos”. In BARROCA, Mário Jorge (coord.) - No tempo de D. Afonso Henriques. Reflexões sobre o primeiro século português. Porto: CITCEM, 2017, pp. 27-69.

MARQUES, Maria Alegria F. - "A restauração das dioceses de Entre Douro e Tejo e o litígio BragaCompostela". In $2^{\circ}$ Congresso Histórico de Guimarães. Vol. V. Guimarães: Câmara Municipal de Guimarães; Universidade do Minho, 1996, pp. 49-84.

MARTÍNEZ MURGUÍA, Manuel - Galicia, 1888. Ed. facs. Barcelona: El Albir, 1981.

MATTOSO, José - "O Condado Portucalense". In SARAIVA, José Hermano (dir.) - História de Portugal. Vol. II. Lisboa: Publicações Alfa, 1983, pp. 3-52.

MATTOSO, José - “A formação de Portugal e a Península Ibérica nos séculos XII e XIII”. In Actas das II Jornadas Luso-Espanholas de História Medieval. Vol. I. Porto: Instituto Nacional de Investigação Científica, 1987, pp. 13-37.

MATTOSO, José (dir.) - História de Portugal. Antes de Portugal. Vol. I. Lisboa: Estampa, 1993.

MATTOSO, José (dir.) - História de Portugal. A Monarquía Feudal (1096-1480), vol. II. Lisboa: Estampa, 1993.

MATTOSO, José - Identificação de um país. Ensaio sobre as origens de Portugal 1096-1325. 2 vols. Lisboa: Estampa, 2008.

MIRANDA, Maria Adelaide; SILVA, José Custódio Vieira da Silva - História da Arte Portuguesa. Época medieval. Lisboa: Universidade Aberta, 1995.

MORALEJO ÁLVAREZ, Serafín - Escultura gótica en Galicia (1200-1350). Santiago de Compostela: Universidad de Santiago de Compostela, 1975. Tesis doctoral.

MUÑOZ PÁRRAGA, M. a Carmen - La arquitectura medieval de la catedral de Sigüenza. Madrid: Universidad Autónoma de Madrid, 1986.

NÚÑEZ RODRÍGUEZ, Manuel - "Inscripciones de la Galicia Altomedieval”. Revista de Guimarães LXXXIX (1979), pp. 293-320.

OLIVEIRA, António Resende de - “Do Reino da Galiza ao Reino de Portugal (1065-1143)”. Revista de História das Ideias 28 (2007) pp. 17-37.

OLIVEIRA, Eduardo Pires de - "Bibliografia artística sobre a Sé Catedral de Braga". Theologica 45/1 (2010), pp. 113-126.

OLIVEIRA, Eduardo Pires de - Guia da Sé de Braga. Vila Nova de Famalicão: Centroatlantico, 2016.

PEREIRA, Paulo (dir.) - História da Arte Portuguesa. Vol. I. Lisboa: Temas e Debates, 1995.

PERLES FONTAO, Juan J. - “Tui dende a arqueoloxía”. In CENDÓN FERNÁNDEZ, Marta; GONZÁLEZ SOUTELO, Silvia (coords.) - Tui: pasado, presente y futuro. Pontevedra: Diputación Provincial de Pontevedra, 2004, pp. 15-33.

PERLES FONTAO, Juan J. - "Castellum Tyde ou a existencia dun xacemento castrexo no conxunto histórico da cidade de Tui: elementos de valoración”. Castellum Tyde 1 (2007), pp. 21-39.

PITA ANDRADE, José Manuel - La construcción de la catedral de Orense. Santiago de Compostela: Cuadernos de estudios gallegos, 1954. 
R. M., J.M.; M.L, R.M.- "Iglesia de Santa María del Azogue”. In Enciclopedia del Románico en España. Zamora. Aguilar de Campoo: Fundación Santa María la Real, Centro de Estudios del Románico, 2012, pp. 188-202.

REAL, Manuel Luís - "O projecto da Catedral de Braga no século XI e as origens do Românico portugués”. In IX Centenário da Dedicação da Sé de Braga. Congresso Internacional- Actas. Vol. I. Braga: Universidade Católica Portuguesa / Cabido Metropolitano e Primacial de Braga, 1990, pp. 435-512.

REAL, Manuel Luís - "O românico português na perspectiva das relações internacionais". In Románico. En Portugal e na Galiza. Lisboa: Fundación Pedro Barrié de la Maza; Fundação Calouste Gulbenkian, 2001, pp. 31-48.

RECHT, Roland - "La circulation des artistes, des oeuvres, des modèles dans l'Europe médiévale". Revue de l'Art 120 (1998), pp. 5-10.

RINCÓN GARCÍA, Wilfredo - "La catedral de Braga y su influencia”. In Summa Artis. Vol. XXX. Arte Portugués. Madrid: Espasa Calpe, 1986, pp. 14-20.

RODRIGUES, Ana Maria; FERREIRA, Manuel Pedro - A catedral de Braga: Arte, liturgia e música dos fins do século XI à época tridentina. Lisboa: Aredasmusas / CESEM, 2002.

RODRIGUES, Ana Paula Leite - Senhores e camponeses num espaço de fronteira: estudo da projecção portuguesa do domínio monástico de Santa Maria de Oia nos séculos XII a XV. Santiago de Compostela: Universidad de Santiago, 2014. Tesis Doctoral.

RODRIGUES, Ana Paula Leite - Nos dois lados do rio Minho. O senhorio transfronteiriço do mosteiro de Santa Maria de Oia (séculos XII a XV). Vigo: Instituto de Estudios Vigueses, 2017.

RODRIGUES, Jorge - "A arte religiosa no românico português e as suas relações com a Galiza: poder e espiritualidade”. In VALLE PÉREZ, José Carlos; RODRIGUES, Jorge - El arte románico en Galicia y Portugal. A Coruña: Fundación Pedro Barrié de la Maza, 2001, pp. 132-155.

RODRIGUES, Jorge - "O Modo Românico". In RODRIGUES, Dalila - Arte Portuguesa. Vol. II. Lisboa: Jornal de Notícias, 2009.

RODRIGUES, Miguel Carlos L. B. Areosa; ALFENIM, Rafael A. E.; LEBRE, Anabela Gomes "Escavação arqueológica de emergência no cruzeiro do transepto da Sé de Braga, notícia preliminar”. In IX Centenário da Dedicação da Sé de Braga. Congresso Internacional - Actas. Vol. I. Braga: Universidade Católica Portuguesa / Cabido Metropolitano e Primacial de Braga, 1990, pp. 173-188.

RODRÍGUEZ BLANCO, José - Apuntes históricos de la Santa Iglesia catedral, ciudad y antigua diócesis de Tuy. Santiago: Imprenta de El Boletín Eclesiástico, 1879.

ROSAS, Lúcia - “Arte románica em Portugal. Contexto Histórico-Artístico”. In PÉREZ GONZÁLEZ, José María (dir.) - Arte Românica em Portugal. Aguilar de Campoo: Fundación Santa María la Real, 2010, pp. 17-44.

SÁ BRAVO, Hipólito de - Rutas del románico en la provincia de Pontevedra. Pontevedra: Caja Rural, 1978.

SÁNCHEZ-PARDO, José - "Las iglesias rurales y su papel en la articulación territorial de la Galicia medieval (ss. VI-XIII). Un caso de estudio”. Mélanges de la Casa de Velázquez. Nouvelle série 40/1, (2010), pp. 149-170.

SÁNCHEZ-PARDO, José - "Los contextos de fundación de las iglesias tardoantiguas en Galicia (ss. V-VIII): sustratos arqueológicos”. AnTard 20 (2012), pp. 255-273. 
SÁNCHEZ-PARDO, José - “Iglesias y dinámicas sociopolíticas en el paisaje gallego de los siglos VVIII". Hispania. LXXIII/ 243 (enero-abril 2013), pp. 11-50.

SÁNCHEZ-PARDO, José - “Organización eclesiástica y social en la Galicia tardoantigua. Una perspectiva geográfico-arqueológica del parroquial suevo”. Hispania Sacra LXVI/ 134 (juliodiciembre 2014), pp. 439-480.

SILVA, José Custódio Vieira da; AFONSO, Luís Urbano - "A arquitectura e a produçâo artística". In RODRIGUES, Ana Maria; FERREIRA, Manuel Pedro - A catedral de Braga: Arte, liturgia e música dos fins do século XI à época tridentina. Lisboa: Aredasmusas / CESEM, 2002, pp. 27-67.

SOARES, Torquato de Sousa - "A inscrição tumular do bispo Nausto de Coimbra (867-912)". Revista Portuguesa de História 1 (1940), pp. 144-148.

SOARES, Torquato de Sousa - "O governo de Portugal pelo Conde Henrique de Borgonha: suas relações com as monarquias Leonesa-Castelhana e Aragonesa”. Revista Portuguesa de História 14/3 (1974), pp. 365-397.

SOTTOMAYOR-PIZARRO, José Augusto de - "O nascimento do reino de Portugal: uma perspectiva nobiliárquica (1096-1157/1300)”. Revista Portuguesa de História 44 (2013), pp. 29-58.

VALLE PÉREZ, José Carlos - La arquitectura cisterciense en Galicia. La Coruña: Fundación Pedro Barrié de la Maza, 1982.

VÁZQUEZ CORBAL, Margarita - “A Arte Românica na Antiga Diocese de Tui: as relações artísticas Galaico-Minhotas”. In MIRANDA, Flávio; SEQUEIRA, Joana; FARIA, Diogo (coords.) - Incipit 2: Workshops de Estudos Medievais da Universidade de Porto 2011-2012. Porto: Universidade de Porto, 2014, pp. 155-164.

VÁZQUEZ CORBAL, Margarita - El arte románico en la antigua diócesis de Tui. Santiago: Universidad de Santiago de Compostela, 2015. Tesis Doctoral.

VÁZQUEZ CORBAL, Margarita - "La influencia gallega en el Románico del Alto Minho”. Mirabilia $26(2018 / 1)$, pp. 1-18.

VILA PÉREZ, Suso - Tui e Valença nos séculos XI a XV. Os acontecementos históricos, sociais, artísticos e económicos. Porriño: Rofer, 2001.

VILA PÉREZ, Suso - A cidade de Tui durante a Baixa Idade Media. Noia: Toxosoutos, 2009.

YZQUIERDO PERRÍN, Ramón - Galicia Arte. Arte medieval (I). Vol. X, A Coruña: Hércules de Ediciones, 1993.

YZQUIERDO PERRÍN, Ramón - “Talleres de Tui, Braga y Zamora en la arquitectura románica del norte de Portugal y Galicia”. Anuario Brigantino 39 (2016), pp. 195-218.

\section{NOTAS}

1. PERLES FONTAO, Juan J. - “Tui dende a arqueoloxía”. In CENDÓN FERNÁNDEZ, Marta; GONZÁLEZ SOUTELO, Silvia (coords.) - Tui: pasado, presente y futuro. Pontevedra: Diputación Provincial de Pontevedra, 2004, pp. 15-33. PERLES FONTAO, Juan J. - "Castellum Tyde ou a existencia dun xacemento castrexo no conxunto histórico da cidade de Tui: elementos de valoración". Castellum Tyde 1 (2007), pp. 21-39. GONZÁLEZ SOUTELO, Silvia - "Arqueología de Tui: el papel del enclave Tude en la Antigüedad". In CENDÓN FERNÁNDEZ, Marta; GONZÁLEZ SOUTELO, Silvia (coords.) - Tui: pasado, presente y futuro. Pontevedra: Diputación Provincial de Pontevedra, 2004, pp. 35-56. 
2. GONZÁLEZ SOUTELO, Silvia - O Tui antiguo: una aproximación histórica-arqueolóxica. Noia: Toxosoutos, 2007, pp. 76-129.

3. SÁNCHEZ PARDO, José - "Iglesias y dinámicas sociopolíticas en el paisaje gallego de los siglos V-VIII”. Hispania LXXIII/ 243 (enero-abril 2013), pp. 11-50, p. 19.

4. AMARAL, Luís Carlos - Formação e desenvolvimento do dominio da diocese de Braga no período da reconquista (século X-1137). Porto: Universidade do Porto, 2007. Dissertação de Doutoramento.

5. SÁNCHEZ PARDO, José - "Iglesias y dinámicas sociopolíticas en el paisaje gallego de los siglos V-VIII", p. 22.

6. MARQUES, José - "Las diócesis portuguesas hasta 1150". In LÓPEZ ALSINA, Fernando (ed.) - El Papado, la Iglesia Leonesa y la Basílica de Santiago a finales del siglo XI. Santiago: Consorcio de Santiago, 1999, pp. 177-214; pp. 194-198. MARQUES, José - “As dioceses portuguesas até 1150". Biblos 78 (2002), pp. 7-59.

7. DÍAZ Y DÍAZ, Manuel C.; VILARIÑO PINTOS, Daría - "La diócesis de Tuy hasta 1100". In GARCÍA ORO, José (coord.) - Historia de las diócesis españolas. Iglesias de Santiago de Compostela y Tuy-Vigo. Madrid: BAC, 2002, p. 541.

8. DÍAZ Y DÍAZ, Manuel C.; VILARIÑO PINTOS, Daría - “La diócesis de Tuy hasta 1100”, p. 541.

9. SÁNCHEZ PARDO, José - "Iglesias y dinámicas sociopolíticas en el paisaje gallego de los siglos V-VIII", p. 20.

10. LÓPEZ ALSINA, Fernando - "La cristalización de Tui como espacio de poder señorial entre 1095 y 1157". In CENDÓN FERNÁNDEZ, Marta; GONZÁLEZ SOUTELO, Silvia (coords.) - Tui: Pasado, presente y futuro. I Congreso de Historia de Tui. Pontevedra: Diputación Provincial, 2004, pp. 57-95, p. 66.

11. SÁNCHEZ PARDO, José - "Iglesias y dinámicas sociopolíticas en el paisaje gallego de los siglos V-VIII", p. 34.

12. DÍAZ Y DÍAZ, Manuel C.; VILARIÑO PINTOS, Daría - “La diócesis de Tuy hasta 1100”, p. 544.

13. Primer obispo históricamente referenciado.

14. MARQUES, José - "Las diócesis portuguesas hasta 1150", p. 197.

15. DÍAZ Y DÍAZ, Manuel C.; VILARIÑO PINTOS, Daría - "La diócesis de Tuy hasta 1100", p. 544. Soneira habría sido usufructuada por los obispos de Tui hasta 915, según por COSTA, Avelino de Jesus da - O bispo D. Pedro e a organização da Arquidiocese de Braga. $2^{\mathrm{a}}$ ed.. Vol. I. Braga: Ed. da Irmandade de São Bento da Porta Aberta, 1997, p. 203.

16. CARRIEDO TEJEDO, Manuel - "Episcopologio tudense, de 911 a 1024". Tui. Museo y Archivo Histórico Diocesano IX (2001), pp. 99-127.

17. Fecha del fallecimiento indicada por COSTA, Avelino de Jesus da - "O Bispo D. Pedro e a organização da diocese de Braga". In IX Centenário da Dedicação da Sé de Braga. Congresso Internacional- Actas. Vol. 1, Braga: Universidade Católica Portuguesa/ Cabido Metropolitano e Primacial de Braga, 1990, pp. 379-434, p. 390.

18. Cronología tomada de COSTA, Avelino de Jesus da - O bispo D. Pedro, vol. I, p. 202, indica que fue quien suscribió el acta de deposición de reliquias en la iglesia de Santiago.

19. Según el orden propuesto en CARRIEDO TEJEDO, Manuel - "Episcopologio tudense, de 911 a 1024", p. 99. Otros autores los sitúan en orden inverso, COSTA, Avelino de Jesus da - O bispo D. Pedro, vol. I, p. 203.

20. CARRIEDO TEJEDO, Manuel - "Episcopologio tudense, de 911 a 1024", p. 99. Según este autor posterior a 1003.

21. En el episcopologio de Lugo desaparecen las menciones a Braga, COSTA, Avelino de Jesus da “O Bispo D. Pedro e a organização da diocese de Braga", p. 391.

22. Consagró San Román de Neiva (Viana do Castelo) antes de 1022. Véase COSTA, Avelino de Jesus da - O bispo D. Pedro, vol. I, p. 203.

23. En agosto de 1068 fijó el censo que el monasterio de San Salvador de la Torre (Viana de Castelo) debía de pagar a la sede de Tui, COSTA, Avelino de Jesus da - O bispo D. Pedro, vol. I, p. 203. 
24. En un documento de 1112 se señala: “... Tuda Civitas Episcopalis, fluvium, quod Sarraceni \& Normanni frequetious solebant intrare, \& Civitatem Tudensem multis praelis undique impugnare. Qua propter venerabilis Naustius, Dei gratia urbis Tudensis Epicopus, Sarracenorum \& Normannorum impugnationis de clinans ad Monasterium Labrugia diffudium fecit", FLÓREZ, Henrique - España Sagrada. Madrid: Antonio Marín, tomo XXII, 1767. Ed. facs. Lugo: Alvarellos, 1992, doc.II, pp . 250-251.

25. CARRIEDO TEJEDO, Manuel - "Obispos de Ourense, Obispos de Tui y Obispos de Lugo (982-1071)”. Diversarum Rerum 12 (2017), pp. 13-52, p. 21.

26. En el interior de la iglesia está la lápida sepulcral de Nausto, obispo de Coimbra: BOUZA BREY, Fermín - "Lauda sepulcral de Nausto, obispo de Coimbra". In Estudios sobre la Monarquía Asturiana, XI centenario de Alfonso II el Casto (1942). Oviedo: Consejo Superior de Investigaciones Científicas, Instituto de Estudios Asturianos, 1950 (2咅 ed. 1971), pp. 275-286, p. 275; SOARES, Torquato de Sousa - "A inscrição tumular do bispo Nausto de Coimbra (867-912)". Revista Portuguesa de História 1 (1940), pp. 144-148. Según la transcripción de NÚÑEZ RODRÍGUEZ, Manuel - “Inscripciones de la Galicia Altomedieval”. Revista de Guimarães LXXXIX (1979), pp. 293-320, p. 319, la lápida dice así: "HIC QVIE/ TVS RECV/ BAT FELICIS/ CORTE NA/VSTIA EPI/SACERDOS QUE LETVS/ CELIS MEN/TE INTVLIT/ ALMA FI/DES DE/GENS CVL/MINE PON/TIFICALI/ CONIM/BRIENSE SEDIS PER/ANNIS XLV RE/QVIES/CENS IN/ HOC TV/MVLO DIE/X CHA/L(EN)D(AS) DEC(EM)BR(I)S ERA $D C C C C / L$ ", que él traduce: "Aquí descansa tranquilo el obispo Naustia de feliz suerte, sacerdote, a quien la fe alimentadora llevo a los cielos ... yaciendo en este sepulcro el día 22 de noviembre del año 912".

27. LÓPEZ ALSINA, Fernando - "La cristalización de Tui como espacio de poder señorial entre 1095 y $1157 "$, pp. 58-61.

28. CARRIEDO TEJEDO, Manuel - "Obispos de Ourense, Obispos de Tui y Obispos de Lugo (982-1071)", p. 17.

29. MANSILLA, Demetrio - "Restauración de las sufragáneas de Braga a través de la reconquista". Revista Portuguesa de História 6 (1955), pp. 117-148, p. 132.

30. "Post non longum uero tempus, crescentibus hominum peccatis, gens Leodemanorum pars maritima est dissipata et, quoniam Tudensis sedis ultima pre omnibus sedibus et infima erat, eius episcopus qui ibi morabatur cum omnibus suis ab ipsis inimicis captiuus duuctus est; et alios occiderunt, alios uendiderunt necnon et/ ipsam ciuitatem ad nichilum reduxerunt, que plurimis annis uidua atque lugubris permansit", LUCAS ÁLVAREZ, Manuel - Tumbo A de la catedral de Santiago. Sada, A Coruña: Ediciós do Castro, 1998, pp. 152-153. LÓPEZ ALSINA, Fernando "La cristalización de Tui como espacio de poder señorial entre 1095 y 1157", p. 63.

31. “... ipsum locum et civitatem Tudensem cum eclesia ibi fundata in nomine Sancti Bartholomaei Apostoli", LÓPEZ FERREIRO, Antonio - Historia de la S.A.M.I. de Santiago de Compostela. Santiago de Compostela: Imp. y enc. del Seminario Conciliar Central, t. II, 1899 , p. 340.

32. LÓPEZ ALSINA, Fernando - "La cristalización de Tui como espacio de poder señorial entre 1095 y $1157 "$, p. 65.

33. IGLESIAS ALMEIDA, Ernesto; MÉNDEZ CRUCES, Plácido - Evocación histórica de la ciudad de Tuy y sus antiguas rúas. Tui: Xuvia, 1990, p. 28, consideraban que había sido en 1070, en la persona del obispo Gregorio.

34. LÓPEZ ALSINA, Fernando - "La cristalización de Tui como espacio de poder señorial entre 1095 y $1157 "$, p. 66.

35. LÓPEZ ALSINA, Fernando - "La cristalización de Tui como espacio de poder señorial entre 1095 y $1157 "$, p. 70.

36. ANDRADE CERNADAS, JOSÉ M. - "Fuentes documentales para el estudio del Rey García de Galicia”, Minius VI (1997), pp. 41-49, p. 47. 
37. FLÓREZ, Henrique - España Sagrada, tomo XXII, p. 246.

38. FLÓREZ, Henrique - España Sagrada, tomo XXII, p. 65. ÁVILA Y LA CUEVA, Francisco

- Historia civil y eclesiástica de la ciudad de Tuy y su obispado. Tomo I. Archivo de la

Catedral de Tui, 1852. Ed. facs. Santiago de Compostela: Consello da Cultura Galega, 1995, p. 97. RODRÍGUEZ BLANCO, José - Apuntes históricos de la Santa Iglesia catedral, ciudad y antigua diócesis de Tuy. Santiago: Imprenta de El Boletín Eclesiástico, 1879, pp.

127-131. MARTÍNEZ MURGUÍA, Manuel - Galicia. Ed. facs. Barcelona: El Albir, 1981, pp. 776-778 se refieren al mes de enero. Ya García Álvarez corrigió la mala lectura ofrecida por los autores que habían seguido a Flórez, y que suponían un desajuste con la cronología del final del reinado de don García, de tal modo que había que dificultades para la comprensión del inicio del episcopado de algunos prelados galleos, así como de la restauración de la sede de Braga, GARCÍA ÁLVAREZ, Rubén - "El diploma de restauración de la sede de Tuy por la infanta Urraca", Cuadernos de Estudios Gallegos 17/52 (1962), pp. 275-292. Sin embargo en COSTA, Avelino de Jesus da - “O Bispo D. Pedro e a organização da diocese de Braga", pp. 379-434, p. 410, todavía se indica enero. Ya en los últimos años el mes que figura es junio VÁZQUEZ CORBAL, Margarita - El arte románico en la antigua diócesis de Tui. Santiago: Universidad de Santiago de Compostela, 2015. Tesis Doctoral, p. 264.

39. LÓPEZ ALSINA, Fernando - "La cristalización de Tui como espacio de poder señorial entre 1095 y $1157 "$, p. 72.

40. CoSTA, Avelino de Jesus da - Liber Fidei Sanctae Bracarensis Ecclesiae. Vol. I Braga: Junta Distrital de Braga, 1965, doc. 61, 62, pp. 84-86.

41. COSTA, Avelino de Jesus da - "O Bispo D. Pedro e a organização da diocese de Braga", p. 410.

42. COSTA, Avelino de Jesus da - O bispo D. Pedro, p. 219.

43. COSTA, Avelino de Jesus da - "O Bispo D. Pedro e a organização da diocese de Braga", p. 413.

44. GARCÍA ÁLVAREZ, Rubén - GARCÍA ÁLVAREZ, Rubén - "El diploma de restauración de la sede de Tuy por la infanta Urraca", pp. 277-278.

45. COSTA, Avelino de Jesus da - Liber Fidei, doc. 20, pp. 40-42.

46. ANDRADE CERNADAS, JOSÉ M. - "Fuentes documentales para el estudio del Rey García de Galicia", p. 47.

47. ANDRADE CERNADAS, JOSÉ M. - "Fuentes documentales para el estudio del Rey García de Galicia", p. 48: "Me parece más discutible la afirmación de la Crónica de Braga en cuanto a que la restauración bracarense fue auspiciada y promovida por los obispos Vistruario de Lugo y Cresconio de Compostela, aunque fuera finalmente completada por García y Sancho II: "Ad quem accedentes Vistrarius episcopus Lucensis et Cresconius Yriensis cum ali is religiosis hominibus et terre militibus rogaverunt eum ut Ecclesiam Bracarensem juberet restaurari et episcopum in ea ordinari [...]". El hipotético deseo restaurador del titular lucense Vistruario, aún sin poder negar esta posibilidad, parece algo extraño ya que ello supone el ver menoscabados parte de sus privilegios".

48. COSTA, Avelino de Jesus da - O bispo D. Pedro, vol. I, p. 223.

49. Así lo señala la Crónica de Braga, en la que se indica: "Rex deinde Sanctius fecit ordinari Petrum Bracarensem episcopum sed nihil ei contulit neque de suis neque ea iam frater eius Garcia dederat", COSTA, Avelino de Jesus da - Liber Fidei, doc. 20, p.40.

50. MARQUES, José - "Las diócesis portuguesas hasta 1150", p. 206.

51. COSTA, Avelino de Jesus da - "O Bispo D. Pedro e a organização da diocese de Braga", pp. 396-397.

52. COSTA, Avelino de Jesus da - "O Bispo D. Pedro e a organização da diocese de Braga", p. 398.

53. COSTA, Avelino de Jesus da - "O Bispo D. Pedro e a organização da diocese de Braga", p. 399.

54. COSTA, Avelino de Jesus da - "O Bispo D. Pedro e a organização da diocese de Braga", pp. 402-403. 
55. MARQUES, José - "Las diócesis portuguesas hasta 1150”, p. 207.

56. MARQUES, José - "Las diócesis portuguesas hasta 1150”, p. 208.

57. MARQUES, José - "Las diócesis portuguesas hasta 1150”, p. 208.

58. MARQUES, José - "Las diócesis portuguesas hasta 1150", p. 207.

59. MARQUES, José - "Las diócesis portuguesas hasta 1150", p. 207.

60. MARQUES, José - “Las diócesis portuguesas hasta 1150”, p. 207.

61. MARQUES, José - "Las diócesis portuguesas hasta 1150”, p. 206.

62. MARQUES, Maria Alegria F. - "A restauração das dioceses de Entre Douro e Tejo e o litígio Braga-Compostela". In $2^{\circ}$ Congresso Histórico de Guimarães. Vol. 5. Guimarães: Câmara Municipal de Guimarães; Universidade do Minho, 1996, pp. 49-84.

63. SOARES, Torquato de Sousa - "O governo de Portugal pelo Conde Henrique de Borgonha: suas relações com as monarquias Leonesa-Castelhana e Aragonesa". Revista Portuguesa de História 14/3 (1974), pp. 365-397. MATTOSO, José - "O Condado Portucalense". In SARAIVA, José Hermano (dir.) - História de Portugal. Vol. 2. Lisboa: Publicações Alfa, 1983, pp. 3-52. MATTOSO, José - "A formação de Portugal e a Península Ibérica nos séculos XII e XIII". In Actas das II Jornadas Luso-Espanholas de História Medieval. Vol. I. Porto: Instituto Nacional de Investigação científica, 1987, pp. 13-37. MATTOSO, José (dir.) - História de Portugal. A Monarquia Feudal (1096-1480). Vol. II. Lisboa: Estampa, 1993. ANDRADE, Amélia Aguiar - Vilas, poder régio e fronteira: o exemplo do Entre Lima e Minho. Lisboa: Universidade Nova de Lisboa, 1994. Dissertação de Doutoramento. BARROS GUIMERÁNS, Carlos - "La frontera medieval entre Galicia y Portugal". Medievalismo. Madrid: Sociedad Española de Estudios Medievales 4 (1994), pp. 27-39. ANDRADE, Amélia Aguiar - "Entre Lima e Minho e Galiza na Idade Média: uma relaçâo de amor e odio". In Carlos Alberto Ferreira de Almeida In Memoriam. Porto: Faculdade de Letras da Universidade do Porto, 1999, pp. 77-91. MARQUES, José - "A Fronteira do Minho. Espaço de Convivência Galaico-Minhota, na Idade Média". In Estudos em Homenagem a Luís António de Oliveira Ramos. Vol. II. Porto: Faculdade de Letras da Universidade do Porto, 2004, pp. 697-712. OLIVEIRA, António Resende de - "Do Reino da Galiza ao Reino de Portugal (1065-1143)". Revista de História das Ideias 28 (2007), pp. 17-37. MATTOSO, José - Identificação de um país. Ensaio sobre as origens de Portugal 1096-1325. 2 vols. Lisboa: Estampa, 2008. FERREIRA, João Paulo Martins - "A Nobreza Galego-Portuguesa da Diocese de Tui (915-1381). Teoria e metodologia". In MIRANDA, Flávio; SEQUEIRA, Joana; FARIA, Diogo (coords.) - Incipit 2: Workshops de Estudos Medievais da Universidade de Porto 2011-2012. Porto: Universidade de Porto, 2012, pp. 41-50. SOTTOMAYOR-PIZARRO, José Augusto de - "O nascimento do reino de Portugal: uma perspectiva nobiliárquica (1096-1157/1300)". Revista Portuguesa de História 44 (2013), pp. 29-58. FLÓREZ DÍAZ, Javier - En busca de una frontera entre Galicia y Portugal: Las tierras miñotas en los siglos XI-XII. Santander: Universidad de Cantabria, 2016-2017.

64. RECHT, Roland - "La circulation des artistes, des oeuvres, des modèles dans l'Europe médiévale”. Revue de l'Art 120 (1998), pp. 5-10.

65. RECHT, Roland - "La circulation des artistes, des oeuvres, des modèles dans l'Europe médiévale", p. 8.

66. RECHT, Roland - "La circulation des artistes, des oeuvres, des modèles dans l'Europe médiévale", pp. 6-7.

67. RECHT, Roland - "La circulation des artistes, des oeuvres, des modèles dans l'Europe médiévale", p. 7.

68. GUILLOUËT, Jean-Marie - "Les transferts artistiques : un outil opératoire pour l'histoire de l'art médiéval?". Histoire de l'art: bulletin d'information de l'Institut national d'histoire de l'art publié en 
collaboration avec l'Association des professeurs d'archéologie et d'histoire de l'art des universités 64 (avril 2009), pp. 17-25.

69. GUILLOUËT, Jean-Marie - "Les transferts artistiques : un outil opératoire pour l'histoire de l'art médiéval?", pp. 17-18.

70. GUILLOUËT, Jean-Marie - "Les transferts artistiques : un outil opératoire pour l'histoire de l'art médiéval?", p. 18.

71. GUILLOUËT, Jean-Marie - "Les transferts artistiques : un outil opératoire pour l'histoire de l'art médiéval?", p.23.

72. Como aproximaciones muy generales destacan OLIVEIRA, Eduardo Pires de - "Bibliografia artística sobre a Sé Catedral de Braga". Theologica 45/1 (2010), pp. 113-126. OLIVEIRA, Eduardo Pires de - Guia da Sé de Braga. Vila Nova de Famalicão: Centroatlântico, 2016.

73. Este aspecto ha sido analizado en CENDÓN FERNÁNDEZ, Marta - "Hipótesis sobre la planta medieval de la catedral de Tuy". El Museo de Pontevedra XLVII (1993), pp. 101-122; CENDÓN FERNÁNDEZ, Marta - La catedral de Tui en época medieval. Pontevedra: Fundación Cultural Rutas del Románico, 1995, pp. 33-45; CENDÓN FERNÁNDEZ, Marta - "El conjunto catedralicio en la Edad Media". In SEARA MORALES, Iago (coord.) - La catedral de Tui desde su plan director. Santiago de Compostela: Xunta de Galicia, 2015, pp. 77-95. En el CD anexo a dicha obra, el capítulo CENDÓN FERNÁNDEZ, Marta - "Memoria histórico artística. La Catedral Medieval”, en concreto pp. 47-57.

74. MORALEJO ÁLVAREZ, Serafín - Escultura gótica en Galicia (1200-1350), Santiago de Compostela: Universidad de Santiago de Compostela, 1975. Tesis doctoral, pp. 100-103; resumen de la tesis doctoral, p. 15.

75. LACERDA, Aarão de - História da Arte em Portugal. Vol. I. Porto: Portucalense Editora, 1942, pp. 185-190, en especial figura 206, p. 181.

76. REAL, Manuel Luís - "O projecto da Catedral de Braga no século XI e as origens do Românico português”. In IX Centenário da Dedicação da Sé de Braga. Congresso Internacional- Actas. Vol. 1, Braga: Universidade Católica Portuguesa / Cabido Metropolitano e Primacial de Braga, 1990, pp. 435-512, p. 455.

77. REAL, Manuel Luís - "O projecto da Catedral de Braga no século XI e as origens do Românico português", pp.455-456.

78. Sobre excavaciones en la zona: RODRIGUES, Miguel Carlos L. B. Areosa; ALFENIM, Rafael A. E.; LEBRE, Anabela Gomes - "Escavação arqueológica de emergencia no cruzeiro do transepto da Sé de Braga, notícia preliminar". In IX Centenário da Dedicação da Sé de Braga. Congresso InternacionalActas. Vol. I. Braga: Universidade Católica Portuguesa / Cabido Metropolitano e Primacial de Braga, 1990, pp. 173-188.

79. REAL, Manuel Luís - "O projecto da Catedral de Braga no século XI e as origens do Românico português”, pp. 456-457.

80. MIRANDA, Maria Adelaide; SILVA, José Custódio Vieira da Silva - História da Arte Portuguesa. Época medieval. Lisboa: Universidade Aberta, 1995, p. 57.

81. SILVA, José Custódio Vieira da; AFONSO, Luís Urbano - "A arquitectura e a produção artística”. In RODRIGUES, Ana Maria; FERREIRA, Manuel Pedro - A catedral de Braga: Arte, liturgia e música dos fins do século XI à época tridentina. Lisboa: Aredasmusas / CESEM, 2002, pp. 27-67.

82. SILVA, José Custódio Vieira da; AFONSO, Luís Urbano - "A arquitectura e a produção artística", pp. 48-49.

83. ALMEIDA, Carlos Alberto Ferreira de - Arquitectura românica de Entre-Douro-e-Minho. Vol. I. Porto: Universidade do Porto, 1978. Tese de Doutoramento, p. 201.

84. ALMEIDA, Carlos Alberto Ferreira de - História da Arte em Portugal. O Românico. Lisboa: Editorial Presença, 2001, pp. 108-109: “Como já fizera Rogério Azevedo, M. Real defendeu que o projecto inicial da Sé de Braga seria do tipo de grande igreja de peregrinação, com transepto de três naves iguais e uma ampla cabeceira que se estenderia para além do actual espaço da catedral. E este projecto, depois drasticamente reduzido, seria já o de D. Pedro. Suponho que não há nenhuma 
razão válida para defender esta posição. Não tem apoio arqueológico, nem histórico e a base do ângulo do topo da nave sul com o transepto nunca foi concebida para ser pilar autónomo. A coluna adossada do lado sul, hoje encoberta por parede, arranca um metro acima do solo e é, muito provavelmente, um contraforte exterior, bem semelhante a outros que encontramos, também exteriormente, na parede da nave norte. Neste caso, a actual solução do transepto saliente, seria mais uma mudança-acrescento ao segundo plano. Seja como tenha sido, só escavações sistemáticas permitirão superar muitas das dúvidas que esta construção nos coloca".

85. BOTELHO, Maria Leonor - "Sé de Braga". In PÉREZ GONZÁLEZ, José María (dir.) - Arte Românica em Portugal. Aguilar de Campoo: Fundación Santa María la Real, 2010, pp. 41-52.

86. BOTELHO, Maria Leonor - "Sé de Braga", p. 41.

87. BOTELHO, Maria Leonor - "Sé de Braga", p. 42.

88. BOTELHO, Maria Leonor - "Sé de Braga", p. 44.

89. CENDÓN FERNÁNDEZ, Marta - "Hipótesis sobre la planta medieval de la catedral de Tuy", pp. 101-122; CENDÓN FERNÁNDEZ, Marta - La catedral de Tui en época medieval, pp. 33-45; CENDÓN FERNÁNDEZ, Marta - “Tui. La catedral en el Románico”. In Enciclopedia del Románico en España. Pontevedra. Vol. II. Aguilar de Campoo: Fundación Santa María la Real, Centro de Estudios del Románico, 2012, pp. 1143-1161. CENDÓN FERNÁNDEZ, Marta - “Memoria histórico artística. La Catedral Medieval", pp. 47-57.

90. BANGO TORVISO, Isidro G. - Arquitectura románica en Pontevedra. La Coruña: Fundación Pedro Barrié de la Maza, 1979, p. 245.

91. VILA PÉREZ, Suso - A cidade de Tui durante a Baixa Idade Media. Noia: Toxosoutos, 2009, pp. 228-234.

92. BANGO TORVISO, Isidro G. - Arquitectura românica, p. 245. Su opinión es seguida por YZQUIERDO PERRÍN, Ramón - Galicia Arte. Arte medieval (I). A Coruña: Hércules de Ediciones, 1993, vol. X, pp. 104-105. Recientemente fue de nuevo planteada la existencia de tres ábsides en MANSO PORTO, Carmen - "Reflexiones sobre la catedral románica y gótica de Santa María de Tui". Abrente: Boletín de la Real Academia Gallega de Bellas Artes de Nuestra Señora del Rosario (2012), pp. 75-126, p. 91.

93. CHAMOSO LAMAS, Manuel - Galicia románica. Madrid: Encuentro, 1979, p. 545.

94. IGLESIAS ALMEIDA, Ernesto - "Los signos lapidarios de la catedral de Tuy en los siglos XII y XIII”, Tuy. Museo y archivo histórico diocesano II (1976), pp. 135-146, pp. 138-139; IGLESIAS ALMEIDA, Ernesto; MÉNDEZ CRUCES, Plácido - Evocación histórica, p. 128.

95. Tui, Archivo Catedral de Tui, Testamento del arcediano de Tui Fernandus Johannis, Becerro I, fol. 131v.-132r.; ap. doc. no I, 20 del Mayo del 1264.

96. Tui, Archivo Catedral de Tui, Testamento de Johan Mouro, pedrero, natural de Valença, Becerro I, fols. 58v.-59r, 5 del Octubre del 1385.

97. “... nque se vendan os ditos beens que lle mando et se de o que por elles deren por amor de Deus por la miña alma para as obras da dita Iglesia de Tuy et do dito mosteyro", Tui, Archivo Catedral de Tui, Testamento de Johan Mouro, fols. 58v.-59r.

98. CENDÓN FERNÁNDEZ, Marta - "El arte medieval en Tui: la catedral como foco receptor y difusor del románico y del gótico". In CENDÓN FERNÁNDEZ, Marta; GONZÁLEZ SOUTELO, Silvia (coords.) - Tui: Pasado, presente y futuro. I Congreso de Historia de Tui. Pontevedra: Diputación Provincial, 2004, pp. 121-155. CENDÓN FERNÁNDEZ, Marta - "La catedral de Tui entre Galicia y Portugal”. In Actas II Congresso Internacional de História da Arte. Coimbra: Almedina, 2005, pp. 727-745. CENDÓN FERNÁNDEZ, Marta - "Una catedral de frontera. Tui y Portugal: afinidades y peculiaridades”. In BECEIRO PITA, Isabel (coord.) - La espiritualidad y la configuración de los Reinos Ibéricos (siglos XII-XV). Madrid: Dykinson, 2018, pp. 91-147. 
99. "que pintara a capella de Santa Eufemea da dita iglesia et lavrara de madeira et tiina en voontade de a procurar et reparar o mellor que podese et Deus lle dese en graçia lles aprouvese de lle dar en lugar a que a fizese dentro della sua sepultura taa su terra en que seu corpo fose sepultado quando o Deus levase desta vida presente e llo aberia en muyta graçia et merçed et os ditos señores dean e cabido vendo que sua demanda era boa et honesta et a reparaçion e corregimento feito ena dita capela de Santa Eufemea et por ser persona auta e habile para o que demandaba otorgoulle sua petiçon [...] et que dea logo cen maravedis vellos Alvaro Vasques canonigo procurador da Hobra da Santa Iglesia para ajuda de cobrir de madeira et tella [...] a torre de dita capella de Santa Oufemia que abre por mingoa do dito tellado e o dito Alvaro de Porto quedou dellos dar logo. Os ditos señores dean et cabido veendo como se espide o tempo de veraao en que a obra da Santa Iglesia a de se reparar espiçialmente de cal por lo estio et tellado en madeira et do presente non abia hi dineiros para os mesteiraas ataa que non reçebesen contas dos procuradores que foron da dita hobra et de os haber doutras partes donde jasia rogaron a Alvaro Vasques canonigo procurador que ora he da dita obra que lles fizese tanta graçia que logo catase mesteiraas et con a madeira que ias enno dito cabido et tella por onde a podese aber cobrise aquella capella de Santa Oufemia ante que mais dampno se lles segise ...". Tui, Archivo Catedral de Tui, El cabildo de Tui concede permiso a Alvaro de Porto para que arregle la capilla de Santa Eufemia y haga allí su sepultura. Protocolo del notario Alonso Fernández, 19 del junio del 1461.

100. CARRO GARCIA, Jesús - Las catedrales gallegas. Buenos Aires: Ediciones Galicia del Centro Gallego de Buenos Aires, 1950, p. 40. SA BRAVO, Hipólito de - Rutas del románico en la provincia de Pontevedra. Pontevedra: Caja Rural, 1978, p. 213. ANÓNIMO "Catedrales. La catedral de Tuy". In OTERO PEDRAYO, Ramón (dir.) - Gran enciclopedia gallega. Tomo VI. Vitoria: Silverio Cañada, 1974, p.44. CHAMOSO LAMAS, Manuel - Tuy. León: Everest, 1981, p. 47.

101. CASTILLO, Ángel del - "La arquitectura en Galicia”. In Geografía General del Reino de Galicia. Generalidades. Vol. II. La Coruña: Ed. Gallega S.A., 1980, p. 898. LAMPÉREZ Y ROMEA, Vicente - Historia de la arquitectura cristiana española en la Edad Media. Madrid: Espasa Calpe, 1930, p. 174, lo apunta entre interrogaciones. BANGO TORVISO, Isidro G. Arquitectura románica, p. 245. MANSO PORTO, Carmen - "Reflexiones sobre la catedral románica y gótica de Santa María de Tui", p. 98 donde se recoge su planteamiento hipotético. VILA PÉREZ, Suso - A cidade de Tui, p. 232 e imagen de la p. 229, hace una propuesta de capillas semicirculares incluidas en la girola.

102. IGLESIAS ALMEIDA, Ernesto; MÉNDEZ CRUCES, Plácido - Evocación histórica, p. 128.

103. LACERDA, Aarão de - História da Arte, p. 188.

104. ALMEIDA, Carlos Alberto Ferreira de - Arquitectura românica, vol. II, p.71.

105. ALMEIDA, Carlos Alberto Ferreira de - Arquitectura românica, vol. II, p.81. Suponemos que se refiere a Paio Mendes.

106. ALMEIDA, Carlos Alberto Ferreira de - Arquitectura românica, vol. II, p. 82.

107. REAL, Manuel Luís - "O projecto da Catedral de Braga no século XI e as origens do Românico português", p. 462.

108. REAL, Manuel Luís - "O projecto da Catedral de Braga no século XI e as origens do Românico português", p. 455.

109. A él se refiere BARREIROS, Manuel Aguiar - A catedral de Santa Maria de Braga. Porto: Marques de Abreu, 1922 (ed. facs. 1999), pp. 96-97. 
110. CHICó, Mário Tavares- A arquitectura gótica em Portugal, Lisboa: Livros Horizonte, 1981, p. 45, fig. 5. ALMEIDA, Carlos Alberto Ferreira de - História da Arte em Portugal. Vol. III. O Românico. Lisboa: Alfa, 1986, p. 70. GRAF, Gerhard N. - Europa românica. Portugal/2. Vol. XIV. Madrid: Encuentro, 1988, p. 215. RODRIGUES, Jorge - "O Mundo Românico". In PEREIRA, Paulo, dir. História da Arte Portuguesa. Vol. I. Lisboa: Temas e Debates, p. 231.

111. REAL, Manuel Luís - "O projecto da Catedral de Braga no século XI e as origens do Românico português", p. 456.

112. REAL, Manuel Luís - "O projecto da Catedral de Braga no século XI e as origens do Românico português", pp. 464-465.

113. REAL, Manuel Luís - "O projecto da Catedral de Braga no século XI e as origens do Românico português", p. 473.

114. SILVA, José Custódio Vieira da; AFONSO, Luís Urbano - "A arquitectura e a produção artística", p. 47.

115. SILVA, José Custódio Vieira da; AFONSO, Luís Urbano - "A arquitectura e a produção artística", p. 34, estampa 2.

116. REAL, Manuel Luís - "O projecto da Catedral de Braga no século XI e as origens do Românico português", p. 462.

117. SILVA, José Custódio Vieira da; AFONSO, Luís Urbano - "A arquitectura e a produção artística", p. 47.

118. En el caso tudense Vila invoca la catedral de Santiago como primer foco de influencia al que añade Santa Fe de Conques, que, por sus pequeñas dimensiones se aproxima más a la catedral de Tui: VILA PÉREZ, Suso - A cidade de Tui, p. 229.

119. REAL, Manuel Luís - "O projecto da Catedral de Braga no século XI e as origens do Românico português", p. 465.

120. Opinión que reiteran SILVA, José Custódio Vieira da; AFONSO, Luís Urbano - "A arquitectura e a produção artística", pp. 48-49.

121. Un resumen de la historiografía sobre esta cuestión en VÁZQUEZ DE PARGA, Luis; LACARRA, José M. ${ }^{\text {; }}$ URÍA RIU, Juan - Las peregrinaciones a Santiago de Compostela. Vol. I. Pamplona: Iberdrola, Gobierno de Navarra, 1992 (ed. facs. de la realizada en 1948 por el C.S.I.C.), pp. 541-554.

122. BANGO TORVISO, Isidro G. - "Las llamadas iglesias de peregrinación o el arquetipo de un estilo". In CARBALlO-CALERO, M ${ }^{\text {a }}$ Victoria (ed.) - El camino de Santiago, camino de las estrellas. Santiago de Compostela : Fundación Caixa Galicia, 1994, pp. 233-284.

123. BRENK, Bea - "Les églises de pèlerinage et le concept de prétention". In BOCK, N.; KURMANN, P.; ROMANO, S, ; SPIESER, J.M. (eds.) - Art, Ceremonial et Liturgie au Moyen Âge. Actes du colloque de 3e Cycle Romand de Lettres Lausanne/Fribourg (2000). Roma : s.e., 2002, pp. 125-139.

124. CARRERO SANTAMARÍA, Eduardo - "Le sanctuaire de la cathédrale de Saint-Jacques-deCompostelle à l'épreuve de la liturgie". In ANDRAULT-SCHMITT, Claude (ed.) - Saint-Martial de Limoges: ambition politique et production culturelle (Xe-XIIIe siècles). Limoges: Pulim, 2006, pp. 295-308. CARRERO SANTAMARÍA, Eduardo - "Retrocapillas, trasaltares y girolas. Liturgia, reliquias y enterramientos de prestigio en la arquitectura medieval”. In FERNÁNDEZ GONZÁLEZ, Etelvina - Estudios in memoriam del Prof. Dr. Fernando Galván Freile. Vol. II. León: Universidad de León, 2010. pp. 63-81. CARRERO SANTAMARÍA, Eduardo - "Comulgar con ruedas de molino. Arquitectura y liturgia medievales o los itinerarios de un desencuentro". Medievalia 15 (2012), pp. 63-66. CARRERO SANTAMARÍA, Eduardo - "Catedral y liturgia medievales. La definición funcional del espacio y sus usos". In SARAIVA, Anísio Miguel de Sousa; MORUJÃO, Maria do Rosário Barbosa (coord.) - Espaços, símbolos e poderes. Liturgia e espaço religioso. Lisboa: Universidade Católica Portuguesa, Centro de Estudos de História Religiosa, 2014, pp. 59-100.

125. Sobre sus relaciones con otros ejemplos: RINCÓN GARCÍA, Wilfredo - "La catedral de Braga y su influencia”. In Summa Artis. Vol. 30. Arte Portugués. Madrid: Espasa Calpe, 1986, pp. 14-20. REAL, Manuel Luís - "O românico português na perspectiva das relações internacionais". In Románico. 
En Portugal e na Galiza. Lisboa: Fundación Pedro Barrié de la Maza; Fundação Calouste Gulbenkian, 2001, pp. 31-48. RODRIGUES, Jorge - "A arte religiosa no românico português e as suas relações com a Galiza: poder e espiritualidade”. In VALLE PÉREZ, José Carlos; RODRIGUES, Jorge - El arte románico en Galicia y Portugal. A Coruña: Fundación Pedro Barrié de la Maza, 2001, pp. 132-155.

126. REAL, Manuel Luís - "O projecto da Catedral de Braga no século XI e as origens do Românico português", p. 482.

127. REAL, Manuel Luís - "O projecto da Catedral de Braga no século XI e as origens do Românico português", p. 478.

128. GASPAR, Alexandra - "Escavações arqueológicas da rua de $\mathrm{N}^{\mathrm{a}} \mathrm{S}^{\mathrm{a}}$ do Leite (Braga)". In IX Centenário da Dedicação da Sé de Braga. Congresso Internacional - Actas. Braga: Universidade Católica Portuguesa / Cabido Metropolitano e Primacial de Braga, 1990, vol. I, pp. 171-172.

129. FONTES, Luís; LEMOS, Francisco S.; CRUZ, Mário - “"Mais Velho” que a Sé de Braga. Intervenção arqueológica na catedral bracarense: notícia preliminar”. Cadernos de Arqueologia 14/15 (1997-98), pp. 137-164, p. 142.

130. REAL, Manuel Luís - "O projecto da Catedral de Braga no século XI e as origens do Românico português", p. 484.

131. REAL, Manuel Luís - “O projecto da Catedral de Braga no século XI e as origens do Românico português", p. 484.

132. REAL, Manuel Luís - "O projecto da Catedral de Braga no século XI e as origens do Românico português", pp. 484-485.

133. YZQUIERDO PERRÍN, Ramón - "Talleres de Tui, Braga y Zamora en la arquitectura románica del norte de Portugal y Galicia”. Anuario Brigantino 39 (2016), pp. 195-218.

134. REAL, Manuel Luís - "O projecto da Catedral de Braga no século XI e as origens do Românico português", p. 474.

135. Como ya indicó PITA ANDRADE, José Manuel - La construcción de la catedral de Orense. Santiago de Compostela: Cuadernos de estudios gallegos, 1954, pp. 40-43.

136. CENDON FERNANDEZ, Marta - "El monasterio de Oia". In YÁÑEZ NEIRA, Fray Damián (coord.) - Monasticon Cisterciense Gallego. Vol. I. León, Edilesa, León, 2000, pp. 197-223.

137. Véase FLÓREZ, Henrique - España Sagrada, docs. VII-IX, pp.261-266, doc. XI, p. 269.

138. VALLE PÉREZ, José Carlos - La arquitectura cisterciense en Galicia. La Coruña: Fundación Pedro Barrié de la Maza, 1982, pp. 47 y 286. Sobre los maestros de Oia, véase FERNÁNDEZ RODRÍGUEZ, Manuel - "El monasterio de Santa María de Oya y sus maestros constructores". Cuadernos de estudios gallegos XI (1957), pp. 219-228.

139. RODRIGUES, Ana Paula Leite - Senhores e camponeses num espaço de fronteira: estudo da protecção portuguesa do domínio monástico de Santa Maria de Oia nos séculos XII a XV. Santiago de Compostela: Universidad de Santiago, 2014. Tesis Doctoral. RODRIGUES, Ana Paula Leite - Nos dois lados do rio Minho. O senhorio transfronteiriço do mosteiro de Santa Maria de Oia (séculos XII a XV). Vigo: Instituto de Estudios Vigueses, 2017.

140. PITA ANDRADE, José Manuel - La construcción de la catedral, 1954, anexo IX, fig. 3, p. 40 .

141. CARRO GARCIA, Jesús - Las catedrales gallegas, p.33.

142. CARRERO SANTAMARÍA, Eduardo - "De la catedral medieval de Ourense y sus inmediaciones. Nuevas hipótesis sobre viejas teorías". Porta da aira: revista de historia del arte orensano 9 (2002), pp. 9-30, en especial fig. 5, p. 29.

143. HIDALGO MUÑOZ, Elena - La Iglesia de Santa María del Azogue de Benavente. Salamanca: Centro de Estudios Benaventanos "Ledo del Pozo", 1995, pp. 24-26. R. M., J.M.; M.L, R.M.- "Iglesia de Santa María del Azogue”. In Enciclopedia del Románico en España. Zamora. Aguilar de Campoo: 
Fundación Santa María la Real, Centro de Estudios del Románico, 2012, pp. 188-202, planta y alzado, p. 190.

144. MUÑOZ PÁRRAGA, M. ${ }^{\text {a }}$ Carmen - La arquitectura medieval de la catedral de Sigüenza. Madrid: Universidad Autónoma de Madrid, 1986, pp. 73-80.

145. COSMEN ALONSO, M. ' Concepción - "Paisajes artísticos velados. La cabecera románica de la catedral de Sigüenza y la posible difusión del modelo". De Arte 15 (2016), pp. 7-32.

146. CARRERO SANTAMARÍA, Eduardo - "La Sé medieval de Lamego: vías de aproximación a un conjunto catedralicio desaparecido”. In SARAIVA, Anísio Miguel de Sousa (coord.) - Espaço, Poder e Memória: A Catedral de Lamego, sécs. XII a XX. Lisboa: Universidade Católica Portuguesa. Centro de Estudos de História Religiosa, 2013, pp. 47-78.

147. LACERDA, Aarão de - História da Arte, fig. 316. DIAS, Pedro - História da Arte em Portugal. Vol. IV. O gótico. Lisboa: Alfa, 1986, pp. 30-33. DIAS, Pedro - A arquitectura gótica portuguesa. Lisboa: Estampa, 1994, pp. 66-68. PEREIRA, Paulo - “A arquitectura (1250-1450)". In PEREIRA, Paulo (dir.) - História da Arte Portuguesa. Vol.1. Lisboa: Temas e Debates, 1995, p. 364.

\section{RESÚMENES}

La sede tudense surge en un espacio que, con el devenir del tiempo, pertenecerá a dos países; los ríos Miño y Limia marcan los límites de esa parte de una diócesis, cuya capital, Tui, poseyó un papel relevante ya desde época romana, con una vinculación fundamental con Braga. Ambas viven los avatares históricos de la Alta Edad Media, y sus sedes episcopales son restauradas casi por las mismas fechas. Tras ello intentan reconstruir sus edificios catedralicios: primero Braga, con un proyecto inicial en buena medida destruido hacia 1110 y después Tui tras un período de reubicación en el monasterio de San Bartolomé. La multiplicación de donaciones permite pensar que la nueva catedral de Tui se inicia hacia 1125, con un transepto de tres naves, similar al de la catedral de Santiago y a la inicial de Braga, así como una cabecera de cinco ábsides semejante a la que plantea el nuevo proyecto bracarense. Estos poseen paralelos en otras catedrales sufragáneas de Braga: además de Tui, Ourense y Lamego. Junto a todo ello existen numerosos intercambios artísticos transfronterizos ya que la diócesis tudense irradia sus modelos a lo largo de sus límites diocesanos, limítrofes con los de Braga.

The Tudense bishopric arises in a space that, with the passing of time, will belong to two countries. The rivers Miño and Limia mark the limits of a diocese whose capital, Tui, had an important role since Roman times, with a fundamental link with Braga. Both, live the historical vicissitudes of the High Middle Ages, and their episcopal sees are restored around the same dates. After that, they tried to rebuild their cathedral buildings: first Braga, with an initial project largely destroyed around 1110 and then Tui after a period of relocation in the monastery of San Bartolomé. The multiplication of donations allows us to think that the new cathedral of Tui began around 1125, with a transept of three naves, similar to that of the cathedral of Santiago and the initial one in Braga, as well as a five-apse chevet, similar to the one proposed by the new bracarense project. These have parallels in other suffragan cathedrals of Braga: in addition to Tui, Ourense and Lamego. Along with all this, there are numerous cross-border artistic 
exchanges since the diocese of Tui radiates its models throughout its diocesan limits, bordering those of Braga.

\section{ÍNDICE}

Keywords: Cathedral, Tui, Braga, artistic exchanges, cross border

Palabras claves: Catedral, Tui, Braga, intercambios artísticos, transfronterizo

\section{AUTOR}

\section{MARTA CENDÓN FERNÁNDEZ}

Universidade de Santiago de Compostela, Facultade de Xeografía e Historia, Departamento de Historia da Arte, 15782 Santiago de Compostela, España. marta.cendon@usc.es. https:// orcid.org/0000-0002-5975-4910 